THEORIA ET HISTORIA SCIENTIARUM, VOL. VI, N 1

Ed. Nicolas Copernicus University 2002

\title{
Appendix
}

\section{Selected metaphor literature $1990-2001$ by Contents}

\author{
Prepared by Tomasz Komendzinski
}

\author{
Barcelona, Antonio, Editor \\ Metaphor and Metonomy at the Crossroads: A Cognitive Perspective
}

1. Antonio Barcelona

Introduction. The cognitive theory of metaphor and metonymy

I. The interaction of metaphor and metonymy and other theoretical issues

2. Antonio Barcelona

On the plausibility of claiming a metonymic motivation for conceptual metaphor

3. Kurt Fey arts

Refining the Inheritance Hypothesis. Interaction between metaphoric and metonymic hierarchies

4. Zoltan Kovecses

The scope of metaphor

5. Gunter Radden

How metonymic are metaphors?

6. Francisco Jose Ruiz de Mendoza Ibanez

The role of mappings and domains in understanding metonymy

7. Mark Turner and Gilles Fauconnier Metaphor, metonymy and binding 
II. Metaphor and metonymy in language structure and in discourse

8. Louis Goossens

Patterns of meaning extension, "parallel chaining", subjectification, and modal shifts

9. Verena Haser

10. Susanne Niemeier

Metaphor in semantic change

Straight from the heart - metonymic and metaphorical explorations

11. Klaus-Uwe Panther and Linda Thornburg

The Effect-For-Cause metonymy in English grammar

12. Peter Pelyvas

Metaphorical extension of may and must into the epistemic domain

13. Margaret Freeman

Poetry and the scope of metaphor: Toward a cognitive theory of literature

14. Diane Ponterotto

The cohesive role of cognitive metaphor in discourse and conversation

15. Esra Sandikcioglu

More metaphorical warfare in the Gulf: Orientalist frames in news coverage

16. Friedrich Ungerer

Muted metaphors and the activation of metonymies in advertising Subject

Index Author Index

ISBN 3-11-0163039

Mouton de Gruyter, Berlin 2000, p. 357

Mouton de Gruyter, Genthiner Str. 13, 10785 Berlin, Germany

Fax: +493026005 222

e-mail: orders@degruyter.de http://www.degruyter.com

Boers, Frank

Spatial Prepositions and Metaphor: A Cognitive Semantic Journey along the UP-DOWN and the FRONT-BACK Dimensions

Part I: Introduction

1. Defining the field of study

2. Objectives

3. Theoretical Framework: Cognitive Semantics

4. Metaphor and Abstract Thought 
5. Metaphor \& Metonymy

6. Methodological Considerations

Part II: Lexico-Semantic Analysis

1. Under

2. Underneath

3. Beneath

4. Below

5. Down

6. In Retrospect 1

7. Above

8. Over

9. UP

10. In Retrospect 2

11. Behind

12. Beyond

13. After

14. Before

15. In front of

16. In Retrospect 3

Part III: Conclusions

1. Overall distributions

2. Prepositions as radial categories

3. Metaphor, metonymy \& convention

4. Contrastive observations References and selective bibliography

ISBN 3-8233-4935-X

Gunter Narr Verlag, Tubingen 1996, p.221

Gunter Narr Verlag, Dischingerwer 5, D-72070 Tubingen, Germany

Cameron, Lynne

\section{Metaphor in Educational Discourse}

1. An applied linguistic approach to metaphor in discourse

2. Talking, thinking and learning: Theoretical background

3. Researching metaphor in classroom discourse 
4. The linguistic form of metaphor in classroom discourse

5. Deliberate and conventionalised metaphor in classroom discourse

6. Metaphor in classroom activity

7. Researching metaphor interpretation

8. Interpreting metaphors in text: 1 The Ozone Layer

9. Interpreting metaphors in text: 2 The Heart

10. Systematicity, metaphor and metonymy

11. Metaphor in educational discourse: Review and discussion

Appendix 1: Linguistic metaphors in the geology lesson

Appendix 2: Linguistic metaphors and teaching sequences in the geology lesson References

Indexes

Hb ISBN 0826449395

Pb ISBN 0826449409

Continuum, 2001.

Continuum International Publishing Group, The Tower Building, 11 York Road, London SE1 7NX.

www.continuumbooks.com

Cameron, Lynne and Low, Graham, eds,

Researching and Applying Metaphor

List of contributors

Acknowledgements

Conventions

Series editors' preface

Preface

I. Key issues in metaphor research

1. Lynne Cameron Operationalising 'metaphor' for applied linguistic research

2. Raymond W. Gibbs, Jr. Researching metaphor

3. Graham Low

Validating metaphor research projects

II. From theory to data

4. James Edwin Mahon

Getting your sources right: What Aristotle didn't say 


\section{Gerard Steen}

Metaphor and discourse: Towards a linguistic checklist for metaphor analysis

6. Lynne Cameron

Identifying and descrabing metaphor in spoken discourse data

III. Analysing metaphor in naturally occurring data

7. David Block

Who framed SLA research? Problem framing and metaphoric accounts of the SLA research process

8. Martin Cortazzi and Lixian Jin

Bridges to learning: Metaphors of teaching, learning and language

9. Alice Deignan

Corpus-based research into metaphor

IV. Analysing metaphor in elicited data

10. Richard Gwyn

„Captain of my own ship": Metaphor and the discourse of chronic illness

11. Graham Low

„This paper thinks...”: Investigating the acceptability of the metaphor AN ESSAY IS A PERSON

12. Zazie Todd and David D. Clarke

When is a dead rainbow not like a dead rainbow? A context-sensitive method for investigating differences between metaphor and simile

References

Index

ISBN 0-521-64022-9; ISBN 0-521-64964-1

Cambridge University Press, Cambridge 1999, p. 295

Cambridge University Press, The Edinburgh Building, Cambridge CB2 2RU, UK

Corradi Fiumara, Gemma

The Metaphoric Process. Connections between Language and Life

1. Connections between language and life An interpersonal approach to metaphoricity

Devaluation and employment of metaphors

Interactive and representatianal concerns 


\section{Metaphor as process}

The metaphoric matrix of theories

2. The life of language An evolutionary perspective The life of language A language for life The limits of a 'lifeless' philosophy Language as metabolic process

3. The interdigitation of fields Propositional and non-propositional factors The questian of boundaries and links Juvenile and adult cognitive style Interepistemic links

4. The oppositional mehaphor On being right in arguments Agreement and disagreement Controversial zeal

5. The maturatian of knowledge Problems of literality The pathology of literalness Cognition and maturity

6. The relationship between digital and analogic styles Notes on the difference between digital and analogic styles Connections between digital and analogic processes Inquiries into discreteness and continuity

The interaction between metaphoricity and literalness The heuristic use of metaphors The quest for accuracy

7. Detachment and participation Embodied philosoghy A scrutiny of detachment Ways of cognitive participation

8. The awareness of metaphoric projections Metaphoric projections Cognitive propensities Embodied experience The circulation of metaphors

9. The metaphoric function The development of identity Meaning, conversation and play Symbolic play and affectual synergies 
The generation and use of links Reciprocity

and silencing Bodily projections

10. Vicissitudes of self-formation Life and language synergies From biological life to dialogic existence Primal interactions

Reception and transmission of metaphors

Notes

Bibliography

Index

ISBN 0-415-12625-8 pbk, ISBN 0-415-12624-X Routledge, London 1995, p. 196

Routledge, 11 New Fetter Lane, London EC4P 4EE, UK

Debatin, Bernhard, Timothy R. Jackson and Daniel Steuer, eds,

Metaphor and rational discourse

Preface

Bernhard Debatin, Timothy R. Jackson, Daniel Steuer

Introduction

Christoph Lepschy

Bernhard reads Kleist -1:a marionette theatre as a writing machine

\section{Lukas Trabert}

Metaphor, rational discourse and the beginning of philosophy in Plato's Theaetetus

Jurgen Barkhoff

Metaphors of the environment and the environment of metaphor in Johann Gottfried Herder's Ideen

David J. Denby

The rational and normative content of metaphors of interiority

Jeanne Riou

imaginative Telepathies'. The re-writing of sensual experience in the age of virtual reality 


\section{Daniel Steuer}

Following telepathy along riverbeds and maelstroms: Freud, Wittgenstein and Benjamin on language and communication

Hans Julius Schneider

Metaphorically created objects: 'real' or'only linguistic'?

\section{Bemd Naumann}

Language and earth: the use of metaphor in geology and linguistics

Timothy R. Jackson

Erotic imagery in medieval spiritual poetry and the hermeneutics of metaphor

Caroline Welsh

Metaphors, method and entropy in Thomas Pynchon

James Edwin Mahon

Truth and metaphor: a defence of Shelley

\section{Bernhard Debatin}

Metaphorical iconoclasm and the reflective power of metaphor

\section{James Livesey}

Metaphor and writing history: a formalist account of historical knowledge

\section{Ann Rigney}

Muddying the waters: metaphor in history

\section{Rebecca L. Spang}

'The fairy circle of words': the many games of Fernand Braudel

Gilbert], Carr

Houston Stewart Chamberlain's 'Foundations' and other constructions of the turn of the century

\section{Alien M. Bass}

The metaphor of the human body in the political theory of John of Salisbury: context and innovation

\section{Siobhdn Donovan}

Metaphor as an instrument of religious discourse and critique of pure reasan in the works of Matthias Claudius 
Andreas Musoiff

International metaphors: bridges or walls in international communication?

Gilnter Bramberger

Kafka's death images

Christoph Lepschy

Bernhard reads Kleist-11: atextas murderer

Oscar Wilde: Amor intellectualis

Notes on the Contributors

ISBN 3-484-10745-6 kart.

Max Niemeyer Verlag GmbH \& Co. KG, Tubingen 1997, p. 264

Deignan, Alice

English Guides, 7: Metaphor

Introduction

1. The human body

1.2 The body

1.6 The head

1.8 The face

1.32 Other parts of the body 1.80

Bones

1.89 Processes in your body

2. Health and Illness

2.2 Health 2.12 Illnesses

2.21 Words related to illnesses 2.46

Words for particular illnesses 2.51

Physical disability

2.61 Injuries

3. Animals

3.2 General words for animals

3.21 Domestic animals 3.40 Farm

animals 3.58 Wild animals 
4. Buildings and Construction

4.2 Construction and building 4.18 Words for buildings and parts of buildings 4.33 Structures and parts of structures 4.47 Entrances

5. Machines, Vehicles, and Tools

5.2 Machines

5.10 Parts of machines

5.43 Tools and working with tools 5.68 Vehicles

6. Games and Sport

6.2 Words used to talk about sport and games 6.16

Words associated with chess

6.21 Cards and card games 6.32 Sport

6.50 Hunting and fishing 6.62 Horse-racing and gambling

7. Cooking and Food

7.2 Preparing food

7.2 Kitchen equipment 7.23 Methods of cooking 7.44 Flavour and taste

8. Plants

8.2 Planis

8.12 Parts of plants 8.27 Flowers 8.39 Fruit

8.46 Cultivating plants

8.71 Growth

8.77 Unhealthy plants

9. Weather

9.2 Sunny and dry weather

9.4 Cold weather

9.11 Clouds and wet weather 9.31 Fog, mist, and haze 9.38 Wind and storms 
10. Heat, Cold, and Fire

10.2 Heat and cold

10.44 Words associated with fire 10.77

Changes in temperature

11. Light, Darkness, and Colour

11.2 Light 11.33 Darkness 11.58 Colour

12. Direction and Movement

12.2 Routes

12.22 Movement upwards and downwards

12.44 Ways of moving Index

ISBN 0-00-370952-3

Harper Collins Publishers, Lodon 1995 (1997), p. 203

Haiper Collins Publishers, 77-85 Fulham Palace Road, London W6 8JB

Denham, A.E.

Metaphor and Moral Experience

Introduction;

1. Art and Morality (Tolstoy and Plato): An Historical Introduction;

2. Values and Valuing;

3. Aspects of Value;

4. Converging on Values: Cognition and Sentiment;

5. The Genesis of Moral Experience;

6. Subjective Conceptions;

7. Identifying Metaphor;

8. Metaphor and Cognition: Two Theories;

9. Metaphor and Judgements of Experience;

Bibliography;

Index

ISBN 0-19-824010-4 Clarendon Press, Oxford 2000, p. 376 
Dirven, Rene,

Metaphor and nation: metaphors Afrikaners live by

Foreword

List of Abbreviations

0. Introduction: Scope of the present metaphor project

1. Metaphor: nature and hunction

1.1. Definition of metaphor

1.2. The structure of metaphor

1.3. Types of metaphor

1.3.1. Types of metaphor according to linguistic level

1.3.2. Types of metaphor according to the proximity of the domains

1.3.3. Types of metaphor according to source and target domains

1.4. Metaphor and thaught

1.4.1. Metaphor and ecological/cultural background

1.4.2. Conceptual metaphors

1.4.3. Metaphor and ideology

1.5. Conclusion and outline of the present study

2. Metaphor and morphology: The case of the Afrikaans diminutive

2.1. The diminutive and its metaphorical extension

2.2. The diminutive in new categorising functions

2.3. Form variants exploited for semantic oppositians

2.4. Conclusion

3. Metaphor and lexis: Divergent developments in Afrikaans and Dutch

3.1 Purposes and rationale of the contrastive analysis

3.2 Image expansion

3.3 Vehicle expansion

3.3.1 Vehicle expansion in Dutch

3.3.2 Vehicle expansion in Afrikaans

3.4 Tenor expansion

3.5 Conclusion on the three expansion processes

3.6 Image reduction

3.6.1 Image reduction in Dutch

3.6.2 Image reduction in Afrikaans

3.7 Vehicle reduction

3.8 Tenor reduction

3.9 Conclusions 
Metaphor and culture: Contrasts between common stock versus new metaphors in Afrikaans 4.0 Introduction

4.1 'Nature' metaphors

4.1.1. Common stock of 'nature' metaphors

4.1.2. New Afrikaans 'nature' metaphors

4.2 'Body and life' metaphors

4.2.1. Common stock of 'body and life' metaphors

4.2.2. New Afrikaans 'body and life' metaphors

4.3 'Psychological state' metaphors

4.3.1. Common stock of 'Psychological state' metaphors

4.3.2. New Afrikaans 'psychological state' metaphors

4.4 'Communication' metaphors

4.4.1. Common stock of 'communication' metaphors

4.4.2. New Afrikaans 'communication' metaphors

4.5. 'Fighting and war' metaphors

4.5.1. Common stock of 'fighting and war' metaphors

4.5.2. New Afrikaans 'fighting and war' metaphors

4.6. 'Social organisation' metaphors

4.6.1. Common stock of 'social organisation' metaphors

4.6.2. New Afrikaans 'social organisation' metaphors

4.7. 'Rural and domestic life' metaphors

4.7.1. 'Path' metaphors

4.7.2. 'Walking and travelling' metaphors 4.7.3 'Chase and catch' metaphors

4.7.4. 'Farm people and work' metaphors

4.7.5. Domestic life' metaphors

\subsection{Conclusion}

Metaphor and language policy: The embrace of English

5.1. Historical background

5.2. Instances of English-influenced expressions

5.3. Analysis of the results in terms of 'language policy'

5.3.1. Comparison with Donaldson's results

5.3.2. Language policy and attitudes

5.3.3. Afrikaner tolerance nnd openness towards English

5.4. Analysis of the main domains of English influence

5.5 Conclusion

Metaphor and ideology: Rural self-contaimnent, apartheid, and ideology of newspapers

6.1. Definition of ideology 
6.2. The Afrikaner social myth of rural self-cantainment 6.2.1. The rise of a new sodoeconomic world

6.2.2. Some features of the rural sodoeconomic world

6.2.3. The end of the sodal myth of rural self-containment

6.3. The imperialist ideology of the language monument at Paarl

6.4. The ideology of newspapers

6.5. Summary and general conclusion Notes References

ISBN 3-631-47864-X

Peter Lang GmbH, Frankfurt am Main 1994, p. 193

Fass, Dan

Processing metonymy ared metaphor

Acknowledgments

Chapter 1

Introduction

1.1 Non-Literal Language

1.2 Metonymy and Metaphor

1.3 Related Semantic Phenomena

1.4 An Approach to Processing Metonymy and Metaphor

1.5 Organization of This Book

1.6 Who This Book May Interest and Why

1.7 Late Additions

Chapter 2. What Is Non-Literal Language?

2.1 Definitions of Literal Meaning

2.2 Relationship Between Non-Literal and Literal Language

2.3 Types of Non-Literal Language

2.4 Interpretation of Literal Language

2.5 Recognition of Non-Literal Language

2.6 Neither Literal Nor Tropical Language

2.7 Review Sumnnary

Chapter 3. What Are Metaphor and Metonymy?

3.1 Relationship Between Metaphor and Metonymy

3.2 What Is Metaphor?

3.3 What Is Metonymy? 
3.4 Interactions of Metaphor nnd Metonymy

3.5 Discussion and Review Summary

Chapter 4. Language Model, Collative Semantics and meta5 Program

4.1 Model of Language

4.2 Collative Semantics and the meta5 Program

Chapter 5. The Representation of Lexical Ambiguity

5.1 Sense-Frames

5.2 Geneza

5.3 Differentiae

5.4 Word Senses as Semantic Primitives

Chapter 6. The Discriminaton of Semantic Relations

6.1 Collation

6.2 Preference-Based Semantic Relations

6.3 Assertion-Based Semantic Relations

6.4 The Co-Existence of Semantic Relatians

6.5 Discussion

Chapter 7. The Representation of Semantic Relations

7.1 Semantic Vectors

7.2 Differences Between Semantic Relations

Chapter 8. The Resolution of Lexical Ambiguity
8.1 Screening
8.2 The Representation of Sentences

Chapter 9. Processing Issues

9.1 The Interaction of Syntax and Semantics

9.2 The Interactian of Collation and Screening

9.3 Finding Sense-Network Paths

9.4 Matching Cells

Chapter 10. Extensions

10.1 Iverson and Helmreich's Metallel

10.2 Implemented Extensiony to meta5

10.3 Further Extensions

Chapter 11. Related Work

11.1 Lingustic and Computational Semantic Theories

11.2 Work on Processing Metonymy or Metaphor 
Chapter 12. Discussion and Conclusions

12.1 Metonymy and Metaphor

12.2 Non-Literal and Literal Language

12.3 Final Thoughts and Conclusions

References

Appendix A: Metaphor Examples with Types

Appendix B: Metaphor Types with Examples

Appendix C : Metonymy Examples with Types

Appendix D: Metonymy Types with Examples

Author Index

Subject Index

ISBN 1-56750-231-8, ISBN 1-56750-232-6 (pbk.)

Ablex Publishing Corporation, Greenwich 1997, p. 501

Ablex Publishing Corporation 55 Old Post Road \#2 P.O. Box 5297 Gi CT 06830, USA

Fernandez, James W., ed.,

Beyond Metaphor: The Theory of Tropes in Anthropology

Contributors

Introduction: Conflusnts of Inquiry James W. Fernandez

Part I. Trope as cognition and poetic discovery Polytropy

Paul Friedrich

The Cultural Basis of Metaphor

Naomi Quinn

Metaphor and Experience: Looking Over the Nation of Image Schema Hoyt

Alverson

Part II. The play of tropes

"We Are Pacrots", "Twins Are Birds": Play of Tropes as Operational S

Terence Turner

Embeding and Transformig Polytrope: The Monkey as Self in Japanese Emiko

Ohnuki-Tierney

Tropical Dominions: The Figurative Struggle over Domains of Belong Apartness in Africa

Debarah Durham and James W. Fernandez 
Part III. Metaphor and coherence of culture

Reasonable and Unreasonable Worlds: Some Expectations of Coherence in Culture Implied by the Prohibition of Mixed Metaphor

Dale Pesman

The Japanese Tea Ceremony Coherence Theory and Metaphor in Social Adaptation Benjamin N. Colby

Bibliography

Index

Stanford University Press, Stanford 1991, p. 298

Forceville, Charles

Pictorial Metaphor in Advertising

List of illustrations Acknowledgements

1 Introduction

2 Max Black's interaction theory of metaphor Introduction

Max Black's interaction theory of metaphor: a first outline An

evaluation of Kittay's (1987) criticisms of Black's theory Other

views held by Black

Summary

3 Towards a theory of pictorial metaphor: Relevant studies

Introduction Wollheim (19871 Hausman (1989) Kennedy (1982) Johns(1984)

Durand (1987) Forceville (1988) Whittock (1990) Summary

4 Advertising: Word and image and levels of context Introduction

The word and image advertisement text

Roland Barthes' (198611964) three kinds of messages

Verbal anchoring and relaying: Franklin (1988)

Pictorial context

Levels of context Summary 
5 Communicator and addresee in the advertising message:

Relevance theory perspectives

Introduction

Sperber and Wilson 's 'relevance theory'

Relevance theory and Black's interaction theory

Relevance theory and the analysis of advertisements and billboards Tanaka (1 Summary

6 Pictorial metaphor in advertisements and billboards: Case studies Introduction Case studies: metaphors with one pictorially present term (MPIs)

Case studies: metaphors with two pictorially present terms (MP2s)

Is there a fundamental difference between MP Is and MP2s?

Case studies: pictorial similes

Discussion

Case studies: verbo-pictorial metaphors (VPMs)

More discussion Summary

7 Individuals' responses to three IBM billboards: An exploratory exper.-eJ Introduction

Background: Mick and Politi (1989)

Hypotheses Stimulus material Method

Participants and procedures Identification of the metaphors: rating method Identification of the metaphors: results Interpretation of the metaphory: scoring criteria Interpretation of the metaphors: results Personal associations of participants Further reflections on the experiment's results Summary

8 Closing remarks Introduction

Variables in the communication situation

Other pictorial tropes

Summary

Notes

Bibliography 
Index

ISBN 0-415-12868-4 (hbk) ISBN 0-415-18676-5 (pbk)

Routledge, London 1998, p. 233

Routledge, 11 New Fetter Lane, London EC4P 4EE

Gerhart, Mary and Russell, Allan Melvin

New Maps for Old. Exploration in Science and Religion

Acknowledgments

Introduction: Mapping Science and Religion Together

I. Metaphoric Process: Reforming Worlds of Meaning in Theology and Natural Science

1. The Role of Metaphoric Process in the Development of Cognitive Complexity

2. Modeling Metaphoric Process

3. Metaphoric Process as the Tectonic Reformation of Worlds of Meaning in Theology and Natural Science

4. Sublimation of the Goddess in the Deitic Metaphor of Moses

II. Bidisciplinary Dialogue and Text in Science and Religion

5. The Genre Bidisciplinary Dialogue

6. A Scientist and a Theologian See the World: Compromise or Synthesis?

7. A Generalized Conception of Text Applied to Both Scientific and Religious Objects

III. Relating Science and Religion

8. Mathematics, Empirical Science, and Theology

9. Limits of Quantum Mechanics and Cosmology as Resources for a Contemporary

10. Theological Metaphysics - With Alternatives

11. Cog Is to Us As We Are to God

12. Myth and Public Science Epilogue

Notes

Bibliography

Index of Names 
Index of Subjects

ISBN 0-8264-1310-2 (hbk) ISBN 0-8264-1338-2 (pbk) Continuum, New York 2001, p. 232 Continuum International Publishing Group Inc 370 Lexington Avenue, New York, NY 10017, USA

Gibbs, Raymond W. Jr. and Steen, Gerard, eds.,

Metaphor in Cognitive linguistics

Introduction

Gerard Steen and Raymond W. Gibbs, Jr Kant, Blumenberg, Weinrich Some

Forgotten Contributions to the Cognitive Theory of Metaphor

Olaf Jakel

Metaphorical Mappings in the Sense of Smell

Iraide Ibarretxe-Antunano

When a Bodily Source Domam Becomes Prominent: The Joy of Counting Metaphors in the Socio-Economic Domain

Frank Boers

From Linguistics to Conceptual Metaphor in Five Steps

Gerard Steen

A Typology of Motivation for Conceptual Metaphor: Correlation vs. Resemblance Joseph Grady Blending and Metaphor

Joseph Grady, Todd Oakley, and Seana Coulson Self and Agency in Religious

Discourse: Perceptual Metaphors for Knowledge at a Marian Apparition Site

Victor Balaban

Taking Metaphor Out of our Heads and Putting It Into the Cultural World

Raymond W. Gibbs, Jr.

Metaphor: Does It Constitute or Reflect Cultutal Models?

Zoltan Kovecses

Metaphors and Cultural Models as Profiles and Bases

Alan Cienki

Congruence by Degree: On the Relation between Metaphor and Cultural Models

Michele Emanatian

ISBN 90-272-3681-X

John Benjamins B.V., Amsterdam 1999, p. 225

John Benjamins Publishing Co., P.O. Box 75577,1070 Amsterdam, The Netherlands 
Gibbs, Raymond W., Jr

The Poetics of Mind. Figurative Thought, Language, and Understanding

Acknowledgments

Chapter 1. Introduction and Overview

Chapter 2. Thinking and Speaking Literary

Chapter 3. Figurative Language Understatnding: A Special Process?

Chapter 4. Metaphor in Language and Thought Chapter 5. Understanding

Metaphorical Expressions Chapter 6. Idiomaticity

Chapier 7. Metonymy

Chapter 8. Irony

Chapter 9. The Poetic Minds of Children

Chapter 10. Implications and Future Directions

References

Name of Index

Subject Index

ISBN 0-521-41965-4 pb ISBN 0-521-42992-7 hb

Cambridge University Press, Cambridge 1994, p. 527

The Pitt Building, Trumpington Street, Cambridge CB2 1RP, UK

http://www.cup.cam.ac.uk

Goatly, Andrew

The Language of Metaphors

List of illustrations List of tables Acknowledgements Typographical conventions List af abbreviadans Introduction

\section{METAPHORICAL AND LITERAL LANGUAGE}

1.1. Introduction

1.2. Matching and similarity

1.3. Metaphor, approximation and prototypicality

1.4. The fuzziness and vagueness of semantic concepts

1.5. Summary 
1.6. Text meanings and negotiation

1.7. Acquisitian of word-meanings

1.8. Meaning change in the lexis of a language

1.9. Clines of metaphoricity

\section{METAPHOR AND THE DICTIONARY: ROOT ANALOGIES}

2.1. Introduction

2.2. Metaphorical patterns in the English lexicon

2.3. Commentary on the map

2.3.1. Metonymy and metaphor

2.3.2. Interplay: multiple determination

2.3.3. Interplay: extensions

2.3.4. Interplay: oppositions

2.3.5. Intetplay: reversal

2.3.6. Metaphorical lexis and diverse structuring of concepts

2.3.7. Influence of phonology/submorphemery as part of langue

2.4. Summary and afterthought

3 METAPHOR AND THE DICTIONARY: WORD-CLASS AND WORDFORMATION

3.1. Word-class and metaphor

3.1.1. Nouns

3.1.2. Nouns referring to processes

3.1.3. Verbs

3.1.4. Adjectives

3.1.5. Adverbs and prepositons

3.1.6. Summary

3.2. Word-formation

3.2.1. Derivation and resembiance: resemblance incorparated in derivation

3.2.2. Derivation and resemblance: resemblance associated with derivation

3.2.3. Conclusion on derivation and metaphor

3.2.4. The effects of derivation on metaphor: two hypotheses

3.2.5. Word-formation and the delicate grammar of metaphorical lexis

3.2.6. Summary

\section{HOW DIFFERENT KIND OF METAPHORS WORK}

4.1. Intraduction

4.2. An improved definition

4.3. Interpretative theories

4.4. Similarity and/or Analogy

4.5. Less central varieties of metaphor

4.6. Summary 


\section{RELEVANCE THEORY AND THE FUNCTIONS OF METAPHOR}

5.1. Metaphor and Relevance Theory

5.2. Functional varieties

5.2.1. Filling lexical gaps

5.2.2. Explanation and modelling

5.2.3. Reconceptualization

5.2.4. Argument by analogy and/or false(?) reasoning

5.2.5. Ideology, the latent function

5.2.6. Expressing emotional attitude

5.2.7. Decoration, disguise and hyperbole

5.2.8. Cultivating intimacy

5.2.9. Humour and games

5.2.10. Metaphorical calls to action at problem-solving

5.2.11. Textual structiuring

5.2.12. Fiction

5.2.13. Enhancing Memorability, Foregrounding and Informativeness

5.2.14. Summary: metaphoric purposes and the functions a/langvage

5.2.15. Functions of metaphors and the familiarity of the Vehicle

\section{THE SIGNALLING OF METAPHOR}

6.1. Introduction

6.2. Which metaphors do we need to mark?

6.3. Domain signallers ar Topic Indicators

6.4. Co-textual markers

6.5. Factivity and the effects of markers: an ambiguity in prepositional attitude

6.6. Subjective metaphors and fantastic literature

6.7. Promiscuity of the markers

\section{THE SPECIFICATION OF TOPICS}

7.1. Introduction

7.2. Copula constructions

7.3. Apposition and other parallelisms

7.4. Genitives

7.5. Premodification

7.6. Compounds

7.7. Blends/portmanteaux

7.8. Topic specification across different parts of speech

7.9. Conclusion and summary on Topic specification/Indication 


\subsection{Proposed Grounds}

8.3. Postposed Grounds

8.4. Pseudo-grounds

8.5. Grounds at greater distances

8.6. Summary: the positioning of G-terms

8.7. Overview of the dines of metaphoric force

\section{THE INTERPLAY OF METAPHORS}

9.1. Introduction: overview oi the framework

9.2. Repetition

9.3. Multivalency

9.4. Diversification

9.5. Modification

9.6. Extension

9.7. Mixing

9.8. Compounding of metaphors

9.9. Literalization of Vehicles

9.10. Overdescription

9.11. Symbolism and the complications of metaphoric interplay

\section{METAPHOR IN ITS SOCIAL CONTEXT}

\subsection{Introduction}

10.2. Development of Relevance Theory: the need for a social dimension

10.3. Halliday's social dimension: a theory of contexts and purposes

10.4. Relevance and social semiotics in Fairclough's model of text interpretation

10.5. Context and the interpretation of metaphor

10.6. Aspects of metaphorical expressions in different genres: a survey and summary

10.7. Postscript: further research

10.8. Suggestians for further work

10.9. Envoi Notes References Index

ISBN 0-415-12876-5 (hbk) ISBN 0-415-12877-3 (pbk)

Routledge, London 1997, p. 360

Routledge, 11 New Fetter Lane, London EC4P 4EE, England 
Gozzi, Raymond. Jr.

The power of metaphor in the age of electronic media

Preface

Foreword, Neil Postman

SECTION ONE: THE POWER OF METAPHOR

1. The Intimate Relations Between Metaphor and Media

Metaphors for Media Media as Metaphors

2. New Media Redescribing the World

Metaphar's Rise to Stardom Descriptions of the World

Redescription as an Ecological Process

3. From Print to Electronic Descriptions of the World

Objectivism

Objectivism, Writing, and Print

The Forms of Electronic Media

Electronic Media Versus Objectivism

The Metaphoric and Metonymic Poles of Discourse

Rock Poetry and "Like"

Summary

4. Metalanguages of Paradox: McLuhan and Derrida

The Oxymetaphor McLuhan

Derrida and the Deconstructionists Summary

5. A Media Ecology History of Metaphor

The Media Ecology Metaphor

The Four Stages of Communication History

Literate Orallty

Metaphor in Oral Societies Writing Culture and metaphor

Print Culture and Metaphor Metaphor in the Electronic

Era

6. Theories of Metaphor

Mapping Systematicity Conceptual Blending Levels of

Metaphor 
Two Additional Perspecaives

7. How To Do a Metaphorical Analysis

Step 1: Identify the Metaphors

Step 2: Explore the Implications of the Metaphors

Step 3: Suggest Alternate Metaphors

Step 4: Who Uses These Metaphors?

Conclusion

\section{SECTION TWO: MEDIA AND METAPHORS}

8. Deep Metaphors for Television

Television as a Conduit Is The Medium a Metaphor?

Television as a Language Television as Environment Summary

9. Why Television Is Not a Text

Differences Between Reading a Text and Watching Television

Unacknowledged Metaphors Have Consequences

The Overexpansion oi the "Text" Metaphor

Three Suggestions for Replacing the Text Metaphor

The Decline of Literacy

Summary

10. Hot and Cool Media - Reworking McLuhan

11. Will the Media Create a Global Village?

12. Life is a Drama - The TV Generation's Metaphor

13. Is Childhood Disappearing Out Here in Televlslonland?

14. Has Metaphor Collapsed?

15. The Fable of the Electric Maps and the Mutating Territory

16. The Technological Race as Metaphor

17. Virtual reality As Metaphor

18. The Conduit Metaphor and "Educatian Reform" The Conduit Metaphor

"Resonance" Metaphors for Communication Conclusion

\section{SECTION THREE: COMPUTERS AND METAPHORS}

19. The Chameleon Computer

Early Attempts to Name the Computer Sttengths and

Limitations of Organic Metaphors Replacing Huinans with

Computers

20. Computer Metaphors that Undermine Human Identity

21. The Cyberspace Metaphor: A Skeptic's View

22. Metaphors Converging, on the Internet 
E-Mail The Web Convergence Hot or Cool?

Publisher or Distributior?

A Work in Progress

23. The Information Superhighway as Metaphor

24. The Computer Virus as Metaphor

25. Artificial Intelligence - Metaphor or Oxymoron?

26. The Computer a Savior and as Spy: Superimposed Metaphors in the News

27. Why We Should Distrust Computers

Where the Map is the Territory Either - or Logic The Bias

of Computers Digital Division Hypotesis Conclusion

Section four: Metaphors in education and knowledge

28. Is Life a Game? Notes onn a Master metaphor

29. Hardball and Softball as Metaphors

30. From the Road to the Fast Track-American Metaphors of Life

31. The Fast Food Franchise as Metaphor

32. McMetaphors

33. Confessions of a Metaphorahollc

34. The Generation X and Boomers Metaphor

35. The Nineties-An Empty Metaghor Waiting to be Filled

36. The Metaphor of the Market

SECTION FIVE: METAPHORS IN EDUCATION AND KNOWLEDGE

37. Economic Metaphors for Education

38. Structure: The Intellectual's Metaphor

39. The Projection Metaphor In Psychology

40. The Jigsaw Puzzle as a Metaphor for Knowledge

SECTION SIX: LANGUAGE DESCRIBING ITSELF

41. Our Inflationaly Language

42. Stalking the Wild Metaphor

43. Is Language a Game?

44. Metaphors by the Seashore

References

Author Index

Subject index 
ISBN 1-57273-122-2, ISBN 1-57273-123-0 (pbk.) Hampton

Press, Inc., Cresskill 1999, p. 295 Hampton Press, Inc. 23

Broadway Cresskill, NJ 47626

Haefliger, Jurg

Imaginationssysteme. Erkenntnistheoretische, anthropologische und mentalitatshistorische Aspekte der Metaphorologie Hans Blumenbergs

1. Einleitung

2. Methodische Uberlegungen

2.1 Kontext und Abgrenzung

2.2 Rhetorik-Begriffe

2.3 Interdisziplinaritat

3. Metaphemtheorien

3.1 Traditionelle Metaphernkritik

3.2 Kognitives Kriterium der Metaphemtheorien

3.3 Nicht-kognitive Metaphemtheorien

3.4 Kognitive Metaphemtheorien

3.4.1 Interaktionstheorie

3.4.2 Kreativitatsthese

3.4.3 Konzeptuelle Metaphern

3.5 Grenzen der Metaphemtheorien

4. Metapher und Erkenntnis bei Blumenberg

4.1 Das kognitive Kriterium

4.2 Nachweis des kognitiven Ansatzes

4.3 Die Hintergehbarkeit der Sprache

4.4 Phanomenologische Aspekte

4.5 Metaphorologie ais Anti-Logik

5. Metapher und Anthropologie bei Blumenberg

5.1 Anthropologischer Anspruch

5.2 Primat der Phantasie

6. Metapher und Geschichte bei Blumenberg

6.1 Metapher und Geschichtsphilosophie

6.2 Metapher und Mentalitatengeschichte

7. Schlussfolgerungen Literatutverzeichnis

ISBN 3-906756-83-1

Peter Lang AG, Bem 1996, p. 162 
Hallyn, Fernand

Metaphor and Analogy in the Sciences

1. R. Harre, et al. Apparatus as Models of Nature

2. J. Meheus. Analogical Reasoning in Creative Problem Solving Processes: Logico- Philosophical Perspectives

3. P. Machamer

The Nature of Metaphor and Scientific Description

4. F. Hallyn Atoms and

Letters

5. G. Simon

Analogies and Metaphors in Kepler

6. W. Shea

Looking at the Moon as another Earth. Terrestrial Analogies and SeventeenthCentury Telescopes

7. J.-P. van Bendegem

Analogy and Metaphor as Essential Tools for the Working Mathematician

8. R.E. Nunez

Conceptual Metaphor and the Embodied Mind: What Makes Mathematics Possible?

9. A.I. Miller

Metaphor and Scientific Creativity

10. G.C. Cornelis

Analogical Reasoning in Modern Cosmological Thinking

11. D.M. Bailer-Jones Scientif Models as Metaphors

12. S. Maasen

Metaphors in the Social Sciences: Making Use and Making Sense of Them

Hardbound, ISBN 0-7923-6560-7

Kluwer Academic Publishers, Dordrecht 2000, 252 pp.

Hintikka, Jaakko, ed.,

Aspects of Metaphor

Preface

Susan Haack - "Dry Truth and Real Knowledge": Epistemologies of Metaphor and

Metaphors of Epistemology 
Robert J. Fogelin - Metaphors, Similes and Similarity

Eric Steinhart and Eva Kittay - Generating Metaphors from Networks: A Formal

Interpretation of the Semantic Field Theory of Metaphor

Bipin Indurkhya - Metaphor as Change of Representation: An Interaction Theory of

Cognition and Metaphor

Jaakko Hintikka and Gabriel Sandu - Mataphor and Other Kinds of Nonliteral Mesning

Noel Carroll - Visual Metaphor

Avishai Margalit and Naomi Goldblum - Metaphors in an Open-Class Test

E. M. Zemach - Metaphors and Ways of Life

Index

ISBN 0-7923-2786-1

Kluwer Academic Publishers, Dordrecht 1994, p. 263

Kluwer Academic Publishers, P.O. Box 322, 3300 Dordrecht, The Netherlands

Hoorn, Johan

\section{Metaphor and the Brain: Behavioral and Psychophysiological Research into Literary Metaphor Processing}

Preface

A two-way procedure of reading

Introduction

Metaphor and the brain Metaphor founds

poetry Metaphor as an understanding

device Aims and definitions

Definition 1: A-, B-, C-term

Definition 2: Literal, metnphoric, and anomalous expressions

Definition 3: Features Definition 4: Context $=$ text Definition 5:

Priming

Chapter 1: The comparison model 1.0 Comparison theory

1.1 Comparison theory in literature

1.2 Comparison theory in psychology

1.3 A formalized model of the comparisan theory

Chapter 2: The anomaly theory

2.0 Anomaly theory

2.1 Anomaly theory in literature 
2.2 Anomaly theory in psychology

2.3 A formalized model of the anomaly theory Chapter 3: The interaction model

3.0 Interactian theory

3.1 Interaction theory in literature

3.2 Interaction theory in psychology

3.3 A formalized model of the interaction theory Outlook on the next Chapters Chapter 4: Stimulus Selection

4.0 The research units

4.1 The theory of literature: Analysis of linguistic properties Constraint 1: Spelling and rhyme

Constraint 2: Syllables and letters

Constraint 3: Word frequency

Constraint 4: Lexical ambiguity (homonymy)

Constraint 5: Linguistic categories Constraint 6:

Syntax

4.2 Psychology: Effects of linguistic properties Constraint 1: No expectation for spelling and rhyme Constraint 2: Small numbers of syllables and letters Constraint 3: Equal word frequency bandwidths Constraint 4: Priming discolves lexical ambiguity (homonymy) Constraint 5: Category verification could intermingle Constraint 6: Equal syntax and fixed A- and B-term distribution

4.3 A priori stimulus selection on linguistic properties

4.4 Test on the selection: Expression categorization and A- and B-term distribution

4.5 Discussion for psychology: Post hoc controls of the constraints 3, 4, and 5 Word frequencies per expression type

Lexical ambiguities per expression type Instancecategory distribution per expression type

4.6 Discussion for the theory of literature Reconsidering spelling and rhyme Reconsidering meter as syllable count Reconsidering word fequency Reconsidering lexical ambiguity (homonymy)

Reconsidering categories and groups of objects

Chapter 5. Feature elicitation

5.0 Feature sets and their comparison

5.1 Theory of literature: Equivalence as similarity, opposition as dissimilarity

5.2 Psychology: Studies on similarity 
Salience and feature set size tie for explaining asymmetry Several formulae to ascertain similarity

5.3 Three definitions for features, their formal and semantic equality, resulting in three measures of feature overlap

5.4 Test of the metaphor models: Feature activation and mapping Deciding among the measures

Results of feature elicitation, 1-f categorization and r-creation

Results of weighted feature set size

Results of weighted shared set size

Discussion of feature set size and shared set size

Is the shared set identical to the interpretation?

Results of the shared sets retrieved in the interpretation sets $\mathrm{Z}$

Discussion of the shared sets retrieved in Z Serial positions ot

feature activation Literal and figurative features at serial positions

Relations at serial positions

Check 1: Asymmetry differences among expression types

Asymmetry of feature sets?

Asymmetry in judgements of similarity and figurativeness? Check

2: The repetition effect Check 3: Word frequency effect Check 4: Lexical ambiguity effect Check 5: Instance - category dominance

5.5 General discussion for psychology

A parallel two-stage anomaly model?

5.6 General discussion for the theory of literature Appendix to Chapter 5

Chapter 6: Reactian time

6.0 The time course of metaphor processing

6.1 What could reaction time say about literature?

6.2 RT studies on metaphor in psychology

6.3 What should an RT study an metaphar provide?

Theoretical discrimination

Controls on design artifact

6.4 RT experiments for metaphors and similes Results for arrival time Results for decison accuracy Discussion of arrival time Check on word frequency Check on lexical ambiguity Discussion of decision accuracy 
6.5 General discussion for psychology

6.6 General discussion for the theory of literature Appendix to Chapter 6 Chapter 7: Electroencephalography

7.0 Psychophysiological traces of metaphor

7.1 Theory of literature: Prudent allusions at psychophysiology Berlyne's arousal theory in literature

7.2 Psychophysiology: Studies on semantic deviations

7.3 A moderate electrocortical effect for metaphors? Right hemispheric?

7.4 ERP experiment on the N400-effect of literary metaphor Results for arrival times

Identification of ERPs

Time slice analysis

Results of the time slice analysis

MANOVA on P300 and N400

Results of MANOVA on P300 and N400

Results for decision accuracy

Discussion of arrival times

Discussion of the N400

Discussion of decision accuracy

7.5 General discussion for psychology

7.6 General discussion for the theory of literature

Appendix to Chapter 7

Conclusions

The parallel two-stage anomaly race model On

MIDAS

MPC: A neural net for metaphars Afterthoughts:

Vivisection of the reader

Summary

Samenvatting

References

Author index

Glossary

ISBN 90-803717-1-8

CIP-Gegevens Koninklijke B bliotheek, Den Haag 1997, PhD. Thesis Vrije Universiteit 
Indurkhya, Bipin

Metaphor and Cognition. An Interactionist Approach

Acknowledgments

Prologue

I The Problem

1 Characterizing Metaphor

1.1 Introduction

1.2 Some Examples of Metaphors

1.3 Characteristics of Linguistic Metaphors

1.4 Degrees of Metaphoric Content: The Conventional vs. the Metaphorical

1.5 Metaphors in Non-Linguistic Domains

1.6 Metaphors, Similes, Analogies and Models

1.6.1 Metaphors and Similes

1.6.2 Metaphors and Analogies

1.6.3 Metaphors and Models

1.7 Conclusions

2 Enter Similarity-Creating Metaphors

2.1 Introduction

2.2 Some Examples af Similarity-Creating Metaphors

2.3 Psychological Studies of the Creation of Similarity

2.4 Creation of Similarity in Metaphor-Related Phenomena

2.4.1 Simile

2.4.2 Analogy

2.4.3 Models

2.5 Similarities and Creative problem Solving

2.5.1 Similarities Before and After the Metaphor

2.5.2 Similarities After but Not Before the Metaphor

2.5.3 Similarities Before but not After the Metaphor

2.6 Conclusions: The Problem of Similarity-Creating Metaphors

3 Approaches to Similarity-Creating Metaphors

3.1 Introduction

3.2 Max Black

3.3 Paul Ricoeur

3.4 Carl Hausman

3.5 Wheelwright - Mac Cormac

3.6 The Lakoffian Approach 


\subsection{My Earlier Approach \\ 3.8 Kittay's Perspectival Theory \\ 3.9 Conclusions}

4 Cognition as Interaction

4.1 Introduction

4.2 Empirical Support for the Interaction View of Cognition

4.2.1 Concepts are More than Aggregates of Sense Data

4.2.2 Concepts can Organize the World Differently

4.2.3 Concepts Cannot Organize the World Arbitrarily

4.2.4 'Universals' and the Physiological Basis of Cognition

4.2.5 Summary

4.3 From Kant to Goodman: Worldmaking

4.4 Piaget's Constructivism

4.5 Lakoff-Johnson: The Bodily Basis of Cognition

4.6 Conclusions

II A Theory

5 An Interactionist Approach to Cognition: Informal Overview

5.1 Introduction

5.2 An Example

5.3 Concept Networks

5.4 Environments and Sensorimotor Data Sets

5.5 Cognitive Relations and Coherency

5.6 Accommodation and Projection

5.7 Cognitive Models

5.7.1 Groupings on the Environment

5.7.2 Accommodation and Projection: Another Perspective

5.7.3 Representation and Description

5.7.4 Some Other Miscellaneous Notions

5.8 Layered Cognitive System and Multiple "Worlds"

5.9 Summary

6 An Interactionist Approach to Cognition: Formal Concepts

6.1 Introduction

6.2 Classes and Groupings

6.3 Relations and Induced Groupings

6.3.1 Preliminary Definition

6.3.2 Difunctional Relations

6.3.3 Relations Within a Class 
6.4 Functions and Operators
6.4.1 Functions
6.4.2 Operators

6.5 Algebras and Structures

6.5.1 Algebras

6.5.2 Descriptions and Structures

6.5.3 Closures and Generating Classes

6.5.4 Closure Over Operators

6.5.5 Computability of Operators

6.6 Subalgebras and Finite Generativity

6.7 Groupings on Algebras: Algebras of Classes

6.8 Relations Between Algebras: Correspondences

6.8.1 Products of Algebras and Correspondences

6.8.2 Groupings Induced by Correspondences

6.8.3 Difunctional Correspondences

6.9 Cognitive Models

6.9.1 Basic Definition

6.9.2 Local Coherency and Coherency

6.9.3 Some Characteristics of Cognitive Models

6.10 Cognitive Models Over an Environment

6.11 Projective snd Accommodating Models

6.12 Finite Representability and Coherency

7 An Interaction Theory of Metaphor

7.1 Introduction

7.2 Metaphor as Projection

7.3 Nomenclature Associated with Metaphor

7.4 Modes of Metaphor

7.4.1 Similarity-Based (Comparative) Metaphors

7.4.2 Similarity-Creating (Projective) Metaphors

7.5 Summary

III The Implications

8 Some Metaphor-Related Issues

8.1 Introduction

8.2 The Thesis 'All Knowledge is Metaphorical'

8.2.1 Version 1: All Knowledge is Projective

8.2.2 Version 2: All Thought is Comparative

8.2.3 Version 3: All Conventional Meanings Arise By Way of Metaphor

8.2.4 Lakoff-Mac Cormac Debate 


\subsection{Metaphor and Correctnes:}

8.3.1 Correctness, Truth and Coherency

8.3.2 Understanding vs. Correctness

5.3.3 Conventianal and Metaphorical Correctness

8.4 Aptness (Quality) of Metaphor

9 On Predictive Analogy and Induction

9.1 Introduction

9.2 Predictive Analogy and Metaphor

9.3 The Search for Logical Justification of Predictive Analogy

9.3.1 Predictive Analogy as an Inductive Process

9.3.2 Predictive Analogy as a First Order Generalization

9.3.3 Predictive Analogy as Second Order Generalization

9.4 The Search for Empirical Justification of Predictive Analogy

9.4.1 Evidence from Classroom Experiments

9.4.2 Evidence from Real-World Problem-Solving Activities

9.5 The 'Dark Side' of Predictive Analogy

9.6 Predictive Analogy and Cognition

9.7 The Problem of Induction

9.8 The Sampling Principle, Randomness, and the Generalized Grue Paradox

9.9 The'Dark Side' of Induction

9.10 Induction in Cognition

10 On Computational Approaches to Metaphor and Analogy

10.1 Introduction

10.2 Computational Approaches to Linguistic Metaphors

10.3 Computational Approaches to Predictive Analogy

10.4 A Computational Model of Creative Analogies: Douglas Hofstadter 10.4.1 An Aside: Context-Sensitivity of Descriptions in Evans' Approach 10.4.2 Resumption: Hofstadttter and Mitchell's Copycat

10.5 Projective (Similarity-Creating) Metaphor in Artificial Intelligence 10.5.1 Projection as 'Top-Down' Grouping

10.5.2 Novel vs. Conventional Projection

10.5.3 The Creation of Similarity

10.6 Modeling Metaphor as Change of Representation

10.7 Conclusions Biblihography Name Index Subject Index 
ISBN 0-7923-1687-8

Kłuwer Academic Publishers Dordrecht 1992, p. 456

Kluwer Academic Publisher, PO. Box 17, 3300 AA Dordrecht, The Netherlands.

\author{
Jakob, Karlheinz \\ Maschine, mentales Modeli, Metapher: \\ Studien zur Semantik und Geschichte der Technik-sprache
}

Inhalt

Vorwort

Teil I: Theoretische Grundlangen

1. Einleitung und Problemstellung

1.1 Was ist eigentlich Technik?

1.2 Der Technik-Begriff in Theorie und Alltag

1.3 Die alltagliche Technik und ihre Geschichte

1.4 Was ist das Besondere am Sprechen iiber Technik?

1.5 Aspekte bisheriger Fachsprachenforschung

2. Anthropologische Aspekte

2.1 Technik ais anthropologische Konstantę

2.2 Organimitation und Organentlastung

2.3 Resonanz und Isomorphie: Mensch, Natur, Technik

2.4 Organprojektion und Metapher

2.5 Teleologisierung der Techanik, historische Relativierung und Bilanz

3. Wissenspsychologische Aspekte
3.1 Vorbemerkung
3.2 Verlebendigungs-Metaphorik: Sprachliche Symptome des Animismus
3.3 Zur Bedeutung der metaphorischen Konzepte
3.4 Die Theorie der Mentalen Modelle
3.5 Folgerungen fur die Linguistik: Analogie, Modeli oder Metapher?
3.6 Wissenserwerb, Analogien und Begriffsbildung
3.7 Mentale Modelle der Techniksprache
3.8 Mentales Modeli I: KÓRPER
3.9 Mentales Modeli II: MENSCH
3.10 Mentales Modeli III: HANDLUNG
3.11 Mentales Modeli IV: MECHANIK
3.12 Stufen des Technikwissen und naive Theorien
3.13 Zwei Versionen eines mentalen Modells
3.14 Bilanz: Verharmlosung und Verschleierung? 
4. Technikgeschichtliche Aspekte

4.1 Die Veranderungen in der Wechselbeziehung von Alltag und Technik

4.2 Die Konservativitat der Artefakte und Begriffe

4.3 Die Gleichzeitigkeit des Ungleichzeitigen

4.4 Industrielle Revolution und Technikkritik

5. Varietatenlinguistische Aspekte

5.1 Alltagssprache und Fachsprachen

5.3 Beziehungen zwischen Technikfachsprache und der Wissenschaftssprache der Physik

5.3 Normierungen in den Techniksprachen

5.4 Die vertikale Gliederung der Fachsprachen

5.5 Fachsprache und Gruppensprache

Teil II: Historische Studien

6. Konzeption und Methode einer Geschichie der Techniksprache in der Neuzeit

6.1 Der Erkenntniswert einer diachronen Untersuchung fiir die Semantik der Techniksprache

6.2 Die Paradigmen der Sprachgeschichtsschreibung und das 19. Jahrhundert

6.3 Zur Konzeption einer Synthese aus Technik-, Begriffs- und Textgeschichte

6.4 Quellenauswahl, Gliederung und Darstellung

7. Das 17. Jahrhundert: Zeitalter der ergotzlichen und niitzlichen Technik

7.1 Technikhistorische und textgeschichtliche Skizze

7.2 Die Deutung der Welt 'sub specie machinae'

7.3 Technomorphie in den physiologischen Schriften von Rene Descattes

7.4 Der ambivalente Maschinenbegriff

7.5 Die Miihle ais Prototyp der antreibenden und der arbeitenden Maschine

7.6 Details der Maschinentechnik: Anfirieb, Bewegung und Arbeitsvenichtung

7.7 Die Hybris der vorindustriellen Pumpentechnik: 'La machine de Marly'

8. Das 18. Jahrhundert: Die Faszination der Feuermaschine und der neue Maschinenbegriff

8.1 Technikhistorische und textgeschichtliche Skizze

8.2 Hohepunkt und Ende des Mensch-Maschinen-Modells

8.3 Physikalische Grundbegriffe in Techniktexten

8.3.1 Kraft, Arbeit und mechanische Energie

8.3.2 Gas und Luft

8.3.3 Dampf

8.3.4 Feuer und Warme 
8.4 Der Maschinenbegriff zwischen Werkzeug und Produktionsmaschine

8.5 Die rationalisierten Automaten

8.6 Klassifikation der nutzlichen Maschinen: Miihle und Wasserkunst

8.7 Wortschatzstudien zur Maschinentechnik: Raderwerk und Kolbenpumpe

8.8 Die Maschine und ihr natiirlicher Antreiber

8.9 Die revolutionare Zasur Technik und Industrie: der erste unnaturliche Antrieb

8.9.1 Die Maschine, die durch Feuer Wasser hebt

8.9.2 Von der Feuermaschine zur Dampfmaschine

8.9.3 Die Vorstellungen von der Selbststeuerung und die Anfange des Dampfmaschinen-Mythos

8.10 Arbeitsmaschine und Kraftmaschine: Erste Ansatze einer neuen Begriffsbildung

9. 1800-1850: Die Verbreitung der Dampfmaschine in Produktion und Verkehr 9.1 Technikhistorische und textgeschichtliche Skizze

9.2 Physikalische Grundbegriffe in Techniktexten

9.2.1 Mechanische und allgemeine Energie

9.2.2 Gas und Dampf

9.3 Die endgiiltige begriffliche Trennung von Werkzeug und Produktionsmaschine

9.4 Der neue Begriff vom Produktionsautomaten

9.5 Die vorindustriellen Prototypen: Muskelkraftmaschine, Wasserkunst und Miihle

9.6 Das Ende der Dampfmachinen-Revolution: Entzauberung, Veralltaglichung und neuer Mythos

9.7 Arbeitsmaschine und Kraftmaschine: Die endgiiltige Lexikalisierung

9.8 Details der Maschinentechnik: Kraftiibertragung, Steuemng und Leistungsangabe

9.9 Fahrzeug, Fuhrwerk und Wagen

9.10 Die erste revolutionare Zasur im Verkehrswesen: das Landfahrzeug mit Dainpfmaschinenantrieb

10. 1850-1910: Die Verbrennungskraftmaschinen, der Motorwagen und das Automobil

10.1 Technikhistorische Skizze

10.2 Textgeschichtliche Skizze

10.3 Grundbegriffe der neuen Energietheorie in Fach- und Vermittlungstexten

10.4 Gemeinsame Modelle und technische Analogien: Dampfmaschine, HeiBiluftmotor und Gasmotor

10.5 Arbeitsmaschine und Kraftsmaschine, Warmekraftmaschine und Verbrennungsmotor

10.6 Konstanz der vorindustriellen Technikmodelle 
10.7 Die zweite revolutionare Zasur im Verkehrswesen: das erste StraBenfahrzeug mit Verbrennungsmotor

10.8 Von der Motorkutsche zum Automobil

10.9 Die Anfange einer Automobil-Subkultur uud die Gruppensprache der Automobilisten

10.10 Die Sprache des Verkehrsrechts: Kraftfahrzeug, Fiihrer und Halter Quellen Literatur

ISBN 3-484-31123-1 ISSN 0344-6778

Max Niemeyer Verlag GmbH \& Co. KG, Tubingen 1991, s. 362

Johnson, Mark

Moral Imagination. Implications of Cognitive Science for Ethics

Preface

Acknowledgments

Introduction: How Cognitive Science Changes Ethics

1. Reason as Force: The Moral Law Folk Theory

2. Metaphoric Morality

3. The Metaphoric Basis of Moral Theory

4. Beyond Rules

5. The Impoverishment of Reason: Our Enlightenment Legacy

6. What's Wrong with the Objectivist Self

7. The Narrative Context of Self and Action

8. Moral Imagination

9. Living without Absolutes: Objectivity and Conditions for Criticism

10. Preserving Our Best Enlightenment Moral Ideals

Notes

Index

ISBN 0-226-40168-5

University of Chicago Press, Chicago 1993, p. 287

Katz, Albert N., Cacciari, Cristina, Gibbs, Raymond W. Jr., and Turner Mark

Figurative Language and Thought

Contributors

1. Figurative Language and Figurative Thought: A Review Albert N. Katz 
2. Figure Mark Turner

3. The Fight Over Metaphor in Thought and Language Raymond W. Gibbs, Jr.

4. Why Do We Speak Metaphorically? Reflections on the Functions of Metaphar in Discourse and Reasoning

Cristina Cacciari

5. Counterpoint Commeatary

Albert N. Katz, Mark Turner, Raymond W. Gibbs, Jr., and Cristina Cacciari Index

ISBN 0-19-510963-5

Oxford University Press, New York 1998, p. 195

Oxford University Press, Inc., 198 Madison Avenue, New York, NY 10016, USA

Kofman, Sarah

\section{Nietzsche and Metaphor}

Translator's Introduction

Translator's Note

Abbreviations

1. Editions of Nietzsche's Works

2. Editions of Other Works Translator's Acknowledgements

I. An Unheard-of and Insolent Philosophy

II. Metaphor, Symbol, Matamorphosis

1. Music, the Privileged Art

2. The Strategic Status of Metaphor

3. The Rehabilitation of Metaphor

4. The Pre-Socratic Model

III. The Forgetting of Metaphor

1. The Originary Metaphorical Activity

2. The Artistic Paradigm

3. The Rethorical Paradigm

4. The Concept
a) Concept and Language
b) Concept and Principle of Reason

5. The Metaphors for Metaphor

6. Genesis of the Concept and Genesis of Justice

7. Forgetting, the Product of a Perspectival Shift 
8. The Role of the Priest

9. Morality; the Ally of Logic

IV. Metaphorical Architectures

1. Architects' Good and Bad Taste

a) The Beehive

b) The Tower, The Bastion, the Stronghold

c) The Egyptian Pyramid and the Roman Columbarium

d) The Spider

2. Saturnalia

V. Nakedness, Dress

1. Proper, Appropriation, Property

2. History, Etymology, Genealogy

3. The Original Text, Homo Natura

VI. Writing, Reading

1. To Have a Thousand Eyes

2. Vertigo

3. Misunderstanding

Appendix; Genealogy, Interpretation, Text

Author's Acknowledgements

Notes

Sarah Kofman: A Complete Bbliography, 1963-1993 Index of

Nietzsche's Works General Index

ISBN 0-485-12098-4 (pbk) ISBN 0-485-11422-4

Athlone Press, London 1993, p. 239

Athlone Press, ! Park Drive, London NW11 7SG, England

Komendzinski, Tomasz, ed.,

\section{Cognitive Science, Metaphor and Conceptual Blending}

[Special Edition of "Cognitive Science and Media in Education”]

Preface

I. Interdisciplinary, Cognitive Science and Representation

1. Mary A. Meyer and Ray C. Paton

Interpreting, Representing and Integrating Scientific Knowledge from Interdisciplinary Projects

2. Peter Gardenfors

Cognitive Science from Computers to Anthillsas Models of Human Thought 
3. Josefa Toribio Normativity: The Hard Problem

II. Metaphor and Cognitive Science

4. Tim Rohrer

The Cognitive Science of Metaphor from Philosophy to Neuropsychology

5. John Bamden, Mark G. Lee

An Artificial Intelligence Approach to Metaphor Understanding

6. Mary Gerhart, Allan Russell

The Role of Metaphoric Process in the Development of Cognitive Complexity

7. Robert Haskell

Cognitive Science and Origin of Lexical Metaphor: A Neurofunctional Shift (NFS) Hypothesis

8. Zoltan Kovecses

Folk and Expert Theories of Emotion and the Disapperance of Psychology

9. Reven Tsur

Some Comments on the Lakoffan Conception of Spatial Imagery III. Conceptual

Blending and Computation

10. Tony Veale

How to Blend Concepts and Influence People: Computational Model of Conceptual Integration

11. Todd Oakley

Conceptual Blending and Philosophical Pairs

Varia

Acknowledgment

ISBN 83-7174-844-2

Wydawnictwo Adam Marszalek, Toruń 2001, p. 307

Wydawnictwo Adam Marszalek, Przy Kaszowniku 37, 87-100 Toruń, Poland info @ marszalek.com.pl

Komendzinski, Tomasz, ed.,

\section{METAPHOR: A Multidisciplinary Approach}

[Special edition of "Theoria et Historia Scientiarum"]

1. Raymond Gibbs, Teenie Matlock

Looking for Metaphor in All the Right Ways 


\section{Tim Rohrer}

The Cognitive Science of Metaphor from Philosophy to Neuropsychology

3. Thomas Leddy

Metaphor and the Philosophy of Art. Dynamic Organicism

4. Guy Bouchard

Metaphore et critique ideologique: les cas Aristotle

5. Anna Wierzbicka

The Semantics of Metaphor and Parable: Looking for Meaning in the Gospels

6. Francisco Ruiz de Mendoza

From Semantic Underdetermination via Metaphor and Metonymy to Conceptual Interaction

7. Antonio Barcelona

Guidelines for the Application of the Theories of Metaphor and Metonymy to Textual Examples

8. Masako Hiraga

The Interplay of Metaphor and Iconicity: Cognitive Approach to Poetic Texts

9. Charles Forceville

Further Thoughts on Delimiting Pictorial Metaphor

10. Albert Katz

Memory -Based and On-line Processing of Metaphoric Sarcasm

11. Reven Tsur.

Some Comments on the Lakoffan Conception of Spatial Imagery

12. Ray Paton

Systemic Metaphors and Integrative Biology

13. Robert Haskell

Cognitive Science and Origin of Lexical Metaphor: A Neurofunctional Shift (NFS) Hypothesis

14. Zoltan Kovecses

Folk and Expert Theories of Emotion and the Disapperance of Psychology

15. Earl MacCormac

Metaphorical Brain: Mind and Consciousness

16. Tony Veale

How to Blend Concepts and Influence People: Computational Model of Conceptual Integration

17. John Barnden, Mark G. Lee

An Artificial Intelligence Approach to Metaphor Understanding

\section{APPENDIX}

18. Tomasz Komendzinski

Selected Metaphor Literature 1990-2001 by Contents (Books) 
ISNN 0-867-4159

Wydawnictwo Uniwersytetu M. Kopernika, Toruń 2001, p.502

Wydawnictwo Uniwersytetu M.Kopernika, Gagarina 11, 87-100 Toruń, Poland www.uni.torun.pl/wyd ksiazki@cc.uni.torun.pl

Kovecses, Zoltan

Metaphor and Emotion. Language, Culture, and Body in Human Feeling

1. Language and Emotion Concepts

2. Metaphors of Emotion

3. Emotion Metaphors: Are They Unique to the Emotions?

4. Events and Emotions: The Subcategorization of Emotions

5. The Force of Emotion

6. Emotions and Relationship

7. Folk Versus Expert Thories of Emotion

8. Universality in the Conceptualization of Emotions

9. Cultural Variation in the Conceptualization of Emotion

10. Emotion Language: A New Synthesis

References

Author Index

Subject Index

Metaphor and Metonymy Index

ISBN 0-521-64163-2

Cambridge University Press, Cambridge 2000, p. 223

The Pitt Building, Trumpington Street, Cambridge CB2 1RP, UK htxp:.//www.cup.cam.ac.uk

Kreitman, Norman

The Roots of Metaphor: A Multidisciplinary Study in Aesthetics

Acknowledgements

Note on the text

Introduction

Chapter 1: The Scope of Aesthetic

Chapter 2: The Biology of Information

Chapter 3: Personal Knowledge and Personal Constructs

Chapter 4: Language, Fantasy and Psychoanalysis

Chapter 5: The Nature of Metaphor

Chapter 6: The Aesthetic Response 
ISBN 1-84014-519-6

Ashgate Publishing Limited, Aldershot 1999, p.218

Ashgate Publishing Limited, Gower House, Croft Road, Aldershot, Hants GU

11 3HR, England

http://www.ashgate.com

ashgate@ cityscape.co.uk

Lakoff, George and Johnson, Mark

Philosophy in the Flesh. The Embodied Mind and Its Challenge to Western Thought

Acknowledgments

A Note on the References

PART I HOW THE EMBODIED MIND CHALLENGES THE WESTERN PHILOSOPHICAL TRADITION

1. Introduction: Who Are We?

2. The Cognitive Unconcious

3. The Embodied Mind

4. Primary Metaphor and Subjective Experience

5. The Anatomy of Complex Metaphor

6. Embodied Realism: Cognitive Science Versus A Priori Philosophy

7. Realism and Truth

8. Metaphor and Truth

PART II THE COGNITIVE SCIENCE OF BASIC PHILOSOPHICAL IDEAS

9. The Cognitive Science of Philosophical Ideas

10. Time

11. Events and Causes

12. The Mind

13. The Self

14. Morality

PART III THE COGNTIVE SCIENCE OF PHILOSOPHY

15. The Cognitive Science of Philosoghy

16. The Pre-Socratic: the Cognitive Science of Early Greek Metaphysics

17. Plato 
18. Aristotle

19. Descartes and the Enlightenment Mind

20. Kantian Morality

21. Analytic Philosophy

22. Chomsky's Philosophy and Cognitive Linguistics

23. The Theory of Rational Action

24. How Philosophical Theories Work

\section{PART IV EMBODIED PHILOSOPHY}

25. Philosophy in the Flesh

Appendix: The Neural Theory of Language Paradigm

References

Index

ISBN 0-465-05673-3

Basic Books, New York 1999, p. 624

Basic Boaks, 10 East $53^{\text {rd }}$ New York, NY 10022-5299, USA

Lakoff, George and Nunez, Rafael E.

Where Mathematics Come From.

How the Embodied Mind Brings Mathematics Into Being

Contents

Acknowledgments ix

Preface

Introduction: Why Cognitive Science Matters to Mathematics

Part I: THE EMBODIMENT OF BASIC ARITHMETIC

1 The Brain's Innate Arithmetic

2 A Brief Introduction to the Cognitive Science of the Embodied Mind

3 Embodied Arithmetic: The Grounding Metaphors

4 Where Do the Laws of Arithmetic Come From?

Part II: ALGEBRA, LOGIC, AND SETS

5 Essence and Algebra

6 Boole's Metaphor: Classes and Symbolic Logic

7 Sets and Hypersets 


\section{Part III: THE EMBODIMENT OF INFINITY}

8 The Basic Metaphor of Infinity

9 Real Numbers and Limits

10 Transfinite Numbers

11 Infinitesimals

Part IV: BANNING SPACE AND MOTION: THE DISCRETIZATION PROGRAM THAT SHAPED MODERN MATHEMATICS

12 Points and the Continuum

13 Continuity for Numbers: The Triumph of Dedekind's Metaphors

14 Calculus without Space or Motion: Weierstrass's Metaphorical Masterpiece Le trou normand: A CLASSIC PARADOX OF INFINITY

Part V: IMPLICATIONS FOR THE PHILOSOPHY OF MATHEMATICS

15 The Theory of Embodied Mathematics

16 The Philosophy of Embodied Mathematics

Part VI: $\boldsymbol{e} \boldsymbol{p} \boldsymbol{i}+1=0$ A CASE STUDY OF THE COGNITIVE STRUCTURE OF CLASSICAL MATHEMATICS

Case Study 1. Analytic Geometry and Trigonometry

Case Study 2. What Is e?

Case Study 3. What Is i?

Case Study 4. $\boldsymbol{e} \boldsymbol{p} \boldsymbol{i}+1=0$ - How the Fundamental Ideas of

Classical Mathematics Fit Together

References

Index

ISBN 0-465-03770-4

Basic Books, New York 2000, p.492

Basic Books, 10 East $53^{\text {rd }}$ St., New York, NY 10022-5299, USA

Lawley, James and Penny Tompkins

Metaphors in Mind: Transformation through Symbolic Modelling

FOREWORD by David Grove 


\section{BACKGROUND KNOWLEDGE}

1. Metaphors We Live By

2. Models We Create By

II THE HEART OF SYMBOLIC MODELLING

3. Less is More: Basic Clean Language

4. Clean Language Without Words

III THE FIVE-STAGE PROCESS

5. Stage 1: Entering the Symbolic Domain

6. Stage 2: Developing Symbolic Perceptions

7. Stage 3: Modelling Symbolic Patterns

8. Stage 4: Encouraging Transformation

9. Stage 5: Maturing the Evolved Landscape

IV IN CONCLUSION

10. Outside and Beyond

V ANNOTATED TRANSCRIPTS Castle Door

Jubilee Clip Lozenge

Summary of Clean Language Questions

Bibliography

Index

About the Authors

ISBN 0-9538751-0-5

The Developing Company Press, London 200, 336 pages

The Developing Company Press, 9 Southwood Lawn Road, Highgate, London N6 5SD, England

http://cleanlanguage.co.uk

Leary, David E., ed.,

Metaphors in the history of psychology

About the authors

Preface

1. Psyche's muse: the role af metaphor in the history af psychology David E. Leary 
2. From metaphors to models: the use of analagy in neuropsychology Karl H. Pribram

3. Inner feelings, works of the flesh, the beast within, diseases of the mind, driving force, and putting on a show: six metaphars of emotion and their theoretical extensions James R. Averill

4. Motives and metaphors: a study in scientific creativity Paul McReynolds

5. Cognitive metaphors in experimental psychology Robert R. Hoffman, Edward L. Cochran, and James M. Nead

6. Metaphors of consciousness and cognition in the history of psychology Jerome Bruner and Carol Fleisher Feldman

7. Metaphors of knowledge and behavior in the behaviorist tradition Laurence D. Smith

8. Metaphor, metatheory and the social world Kenneth J. Gergen

9. Metaphors of unwanted conduct: a historical sketch Theodore R. Sarbin

10. Generative metaphor and the history of psychological discourse Kurt Danziger

11. Metaphor, theory, and practice in the history of psychology David E. Leary

Name Index

Subject Index

ISBN 0-521-37166-X ISBN 0-521-42152-7 pbk

Cambridge University Press, Cambridge 1990 [1992, 1994], p. 383 The Pitt Building, Trumpington Street, Cambridge CB2 1RP, UK http://www.cup.cam.ac.uk

Leezenberg, Michiel

\section{Contexts of Metaphor: Semantic and Conceptual Aspects of Figurative Language Interpretation}

Preface.

Introduction.

I. From the History of Metaphor.

The Pre- and Protohistory of Metaphor. Prehistorical and preliterate societies. 
Metaphor in Mesopotamia: Sumer and Akkad.

Aristotle on Metaphor, Comparison, and Similarity.

Abd al-Qahir al-Jurjani's Mysteries of Eloquence.

Giambattista Vico: Metaphor and the Origin of Language.

II. Twentieth-Century Views of Metaphor.

Semantic Approaches.

Referentialist views.

Descriptivist views.

Intermezzo: metaphor in generative grammar.

Pragmatic Approaches.

The Gricean program.

Searle.

The Davidsonian Program: Metaphor Without Meaning.

Conceptualist Approaches: Cognitive Semantics.

III. Metaphor and Context.

Metaphor and Context-Dependence.

Kaplan's logic of demonstratives.

Context-dependence of property expressions.

Metaphor and the logic of demonstratives.

A comparison: Stem's 'metaphor as demonstrative'. Metaphorical Assertion.

Stalnakerian views of assertion.

Pragmatic intrusion: the neo-Gricean program.

Thematic dimensions, presupposition, and assertion.

Extensions: scope and shift of dimensions.

Novel metaphor.

IV. Metaphor, Concept, and Society.

Conceptualist Views of Metaphor: A Radical Critique.

Extending cognitive semantics: Gibbs \& Indurkhya.

A Wittgensteinian critique of concepts.

Metaphor and Concept Formation: A Vygotskyan Approach.

Vygotsky: concepts, language, and context.

Similarity and the role of theories.

Concepts and metaphor.

Beyond Literal Meaning.

Bibliography.

Index. 
ISBN: 0-08-043881-4,

Elsevier Science, 2001, 332 pages

Maasen, Sabine, Everett Mendelsohn and Peter Weingart, eds,

Biology as Society, Society as Biology: Metaphors

S. Maasen, E. Mendelsohn, P. Weingart

Introduction: Metaphors: Is There a Bridge over Troubled Waters?

Part I: Metaphors Revalued.

1. S. Maasen

Who is Afraid of Metaphors?

2. L. Daston

How Nature became the Other: Anthropomorphism and Anthropocentrism in Early Modem Natural Philosophy

3. R. Falk

The Manifest and the Scientific

4. R. Wokler

The Nexus of Animal and Rational: Sociobiology, Language, and the Enlightenment Study of Apes

Part II: 'Struggle'.

5. P. J. Bowler

Social Metaphors in Evolutionary Biology, 1870-1930: the Wider Dimension of Social Darwinism

6. P. Weingart

'Struggle for Existence': Selection and Retention of a Metaphor Part III:

'Evolution' and 'Organism'.

7. PM. Hejl

The Importance of the Concepts of 'Organism' and 'Evolution' in Emile Durkheim's Division of Social Labor and the Influence of Herbert Spencer

8. A. la Vergata

Herbert Spencer: Biology, Sociology, and Cosmic Evolution

9. S.D. Mitchell

The Superorganism Metaphor: Then and Now 
10. G. Mitman

Defining the Organism in the Welfare State: the Politics of Individuality in American Culture, 1890-1950

Part IV: Economics

11. T.L. Alborn

A Plague upon Your House: Commercial Crisis and Epidemic Disease in Victorian England

12. M.S. Morgan

Evolutionary Metaphors in Explanations of American Industrial Competition;

13. G.M. Hodgson

Biological and Physical Metaphors in Economics

ISBN 0-7923-3174-5

ISBN 1-4020-0251-3

Kluwer Academic Publishers, Dordrecht 1995, 2001, 364 pp.

Maasen, Sabine and Peter Weingart

Metaphors and the Dynamics of Knowledge

List of figures and tables

Acknowledgments

Foreword

Metaphors and the dynamics of knowledge: preliminary thoughts

1. Analysing knowledge dynamics, in general, and the role of metaphors, in particular

Observing the dynamics of 'ideas' in society

Changing the observatory: a system-theoretical and discourse-analytical approach

2. Metaphors as targets and tools in the analysis of knowledge dynamics

Troubling terms

Metaphor analysis from 'above', from 'below', and from 'in between' Metaphor analyses of knowledge dynamics

3. 'Struggle for existence': selection, retention and extinction of a metaphor

Vignette

Functions and dysfunction of metaphors in science 
Kampfums Dasein - popularization and contexts of usage A change of context: Weismann and the Krupp competition The metadiscourse on 'struggle for existence'

4. Of paradigms, shifts, and changes - the Kuhnian metaphor

Vignette

Thomas Kuhn's Structure - 'The right text at the right time'

The 'Kuhnianization' of the social sciences

Paving the way for postmodernism - the Kuhnian metaphor at work Kuhn, bartenders, theologians, and ice-cream parlours

5. The order of meaning: the career of chaos as a metaphor

Vignette

Introduction

The Career of chaos as a metaphor

Chaos in contemporary social science discourses

Metaphor transfer - discursive order out of/within chaos ?

6. Metaphors and the dynamics of knowledge

Struggle, Kuhn, and chaos: changing metaphors denoting change Struggle, Kuhn, and chaos: how metaphors create something new Dynamics of

Notes knowledge: from memes to metaphors

References

Author index

Subject index

ISBN 0-415-20802-5

Routledge, London 2000, p. 185

Routledge, Taylor \& Francis Group, 11 New Fetter Lane, London EC4P 4EE, England

Mio, Jeffrey Scott and Katz, Albert N., eds

Metaphor: Implications and Applications

Preface

Part I: Pragmatics of Metaphor 1. Albert Katz

On Interpreting Statements as Metaphor or Irony: Contextual Heuristics and Cognitive Consequences 


\section{Roger J. Kreuz}

The Use of Verbal Irony: Cues and Constraints

3. Valerie F. Reyna

Meaning, Memory, and the Interpretation of Metaphors

Part II: Metaphors in Clinical Settings

4. Linda M. McMullen and John B. Conway

Conceptualizing the Figurative Expressions of Psychotherapy Clients

5. Lynne E. Angus

An Intensive Analysis of Metaphor Themes in Psychotherapy

6. Anne M. Rose

Metaphors in Child Custody Mediation: Utilizing Symbolic Language to Facilitate Agreements

7. William P. Banks and Suzanne C. Thompson

The Mental Image of the Human Body: Implications of Physiological Mental

Models for our Understanding of Health and Illness

Part III: Metaphors and Politics

8. Jeffrey Scott Mio

Metaphor, Politics, and Persuasion

9. Warren S. Gramm

Economic Metaphors: Ideology, Rhetoric, and Theory

10. Patricia A. Chantrill and Jeffrey Scott Mio

Metonymy in Political Discourse

11. Seth Thompson

Politics Without Metaphors is Like a Fish Without Water

Part IV: The Metaphors of Everyday Life

12. Paul Whitney, Desiree Budd, and Jeffrey Scott Mio

Individual Difference in Metaphoric Facilitation of Comprehension

13. John M. Kennedy

Metaphor in Tactile Pictures for the Blind: Using Metonymy to Evoke

Classification

14. Howard R. Pollio

Boundaries in Humor and Metaphor Author Index Subject Index

ISBN 0-8058- 1650-X

Lawrence Erlbaum, Mahwah 1996, p. 269

Lawrence Erlbaum Associate, Inc., Publishers, 10 Industsial Avenue, Mahwah, New Jersey 07430, USA 


\section{Nehaniv, Chrystopher L., ed, Computation for Metaphors, Analogy, and Agents}

\section{INTRODUCTION}

Computation for Metaphors, Analogy and Agents

Chrystopher L. Nehaniv (University ofAizu, Japan \& University of Hertfordshire, U.K.)

\section{METAPHORS AND BLENDING}

Forging Cannections

Mark Turner (University of Maryland, U.S.A.)

Rough Sea and the Milky Way: Blending' in a Haiku Text

Masako K. Hiraga (University of the Air, Japan)

Pragmatic Forces in Metaphor Use: The Mechanics of Blend Recruitment in Visual

Metaphors

Tony Veale (Dublin City University, Ireland)

\section{EMBODIMENT: THE FIRST PERSON}

The Cog Project: Building a Humanoid Robot

Rodney A. Brooks, Cynthia Breazeal, Matthew Marjanovic, Brian Scassellati, Matthew M. Williamson (MIT Artificial Intelligence Lab, U.SA.)

Embodiment as Metaphor: Metaphorizing-In the Environment Georgi Stojanov (SS Cyril \& Methodius University, Macedonia)

\section{INTERACTION: THE SECOND PERSON}

Embodiment and Interaction in Socially Intelligent Life-Like Agents Kerstin Dautenhahn (University of Reading, U.K.)

An Implemented System for Metaphor-Based Reasoning with Special Application to Reasoning about Agents

John A. Barnden (University of Birmingham, U.K)

GAIA: An Experimental Pedagogical Agent fnr Exploring Multimodal Interaction Tom Fenton-Kerr (University of Sydney, Australia)

When Agents Meet Cross-Cultural Metaphor: Can They Be Equipped to Parse and Generate It?

Patricia O’Neill-Brawn (Japan Technology Program, U.S. Dept. of Commerce)

\section{IMITATION: FIRST AND SECOND PERSON}

Imitation and Mechanisms of Joint Attention: A Developmental Structure for 3uilding Social Skills on a Humanoid Robot

Brian Scassellati (MIT Artificial Intelligence Lab. U.S.A. ) 
Figures of Speech, a Way to Acquire Language

Armeli Kauppinen (University of Helsinki \& Helsinki Polytechnic, Finland)

\section{SITUATED MAPPING: SPACE AND TIME}

"Meaning" through Clustering by Self Organization of Spatial and Temporal Information Ulrich Nehmzow (University of Manchester. U.K.)

Conceptual Mappings from Spatial Motion to Time: Analysis of English and Japanese Kazuko Shinohara (Otsuma Women's University, Japan)

\section{ALGEBRAIC ENGINEERING: RESPECTING STRUCTURES}

An Introduction to Algebraic Semiotics, with Application to User Interface Design Joseph Goguen (University of California, San Diego, U.S.A.)

An Algebraic Approach to Modeling Creativity of Metaphor Bipin Indurkhya (Tokyo University of Agriculture and Technology, Japan) Metaphor and Human-Computer Interaction: A Model Based Approach J. L. Alty and R. P. Knott (Loughborough University, U.K.)

\section{A SEA-CHANGE IN VIEWPOINTS}

Empirical Modelling and the Foundations of Artificial Intelligence

Meurig Beynon (University of Warwick, U.K.)

Communication as an Emergent Metaphor for Neuronal Operation

Stawomir J. Nasuto, Kerstin Dautenhahn, and Mark Bishop (University of Reading, U.K.)

The Second Person - Meaning and Metaphors

Chrystopher L. Nehaniv (University ofAizu, Japan \& University of Hertfordshire, U.K.) Author Index

ISBN 3-540-65959-5

Springer-Verlag, Berlin 1999 p. 388

Nogales, Patti D.

\section{Metaforically Speaking}

Introduction: Why Metaphor

1. Metaphor as Reconceptualization

2. Metaphor, Semantics and Pragmatics 
3. A Critique of Metaphor as Meaning

4. Metaphor as Use: Metaphor and Lies

5. Metaphor as Use: Metaphor and Irony

6. Metaphor as Use: Metaphor and Indirect Speech Acts

7. Evaluation of the Analysis: Conditions on a Theory of Metaphor Index

ISBN 1-57586-159-3 (pbk) ISBN 1-57586-158-5

CSLI Publications, Stanfordt 1999, p. 241

Olds, Linda E.

Metaphors of Interrelatedness: Toward a Systems Theory of Psychology

Preface

Introduction: Mindscapes and Metaphor

Part One: Bare Bones

Prologue

Chapter 1. Knowledge as Approximation

Chapter 2. The Necessity of Metaphor

Chapter 3. Broadening the Research Paradigm

Part Two: Flesh and Tissue

Prologue

Chapter 4. Metaphors for the Self

Chapter 5. Models of Interrelatedness: The Emergence of Systems Theory Chapter 6.

Toward a Process Psychology: Systems Metaphors of Self and Change

Part Three: Indra's Net

Prologue

Chapter 7. Images of Wholeness: Toward a Unifying Systems Metaphor Notes

Bibliography

Index

ISBN 0-7914-1012-9

State University of New York Press, New York 1992, p. 217 
Ortony, Andrew, ed.,

\section{Metaphor and Thought}

List of contributors

Preface to the second edition

Preface to the first edition

1. Metaphor, language, and thought Andrew Ortony

METHAPOR AND MEANING

2. More about metaphor Max Black

3. Figurative speech and linguistics Jerrold M. Sadock

4. The semantics of metaphor L. Jonathan Cohen

5. Some problems with the notion of literal meanings David E. Rumelhart

6. Metaphor John R. Searle

7. Language, concepts, and worlds: Three domains of metaphor Samuel R. Levin

8. Observations on the pragmatics of metaphor Jerty L. Morgan

\section{METHAPOR AND REPRESENTATION}

9. Generative metaphor: A perspective on problem-setting in social policy Donald A. Schon

10. The conduit metaphor: A case of frame conflict in our language about language Michael J. Reddy

11. The contemporary theory of metaphor George Lakoff

12. Process and product in making sense of tropes Raymond W. Gibbs, Jr.

13. Metaphor, itiduction, and social policy: The convergence of macroscopic and microscopic views

Rubert. J. Sternberg, Roger Touraugeau, and Georgia Nigro

METAPHOR AND UNDERSTANDING

14. Psychological processes in metaphor comprehension and memory Alan Paivio and Mary Walsh

15. The interpretation of novel metaphors Bruce Fraser 
16. The role of similarity in similes and metaphors Andrew Ortony

17. Images and models, similes and metaphors George A. Miller

18. How metaphors work Sam Glucksberg and Boza Keysar

19. Metaphor and irony: Two levels of understanding Ellen Winer and Howard Gardner

METAPHOR AND SCIENCE

20. The shift from metaphor to analogy in Western science Dedre Gentner and Michael Jeziorski

21. Metaphor and theory change: What is "metaphor" a metaphor for? Richard Boyd

22. Metaphor in science Thomas S. Kuhn

23. Metaphorical imprecision and the "top-down" research strategy Zenon W. Pylyshyn

24. The instructive metaphor: Metaphoric aids to students' understanding of science Richard E. Mayer

25. Metaphor and learning Hugh G. Petrie and Rebeca S. Oshlag

26. Learning without metaphor Thomas F. Green

27. Educational uses of metaphor Thomas G. Sticht

References

Author index

Subject index

Cambridge University Press, Cambridge 1993 (second edition), reprinted 1994, 1995, 1996, p. 678

Cambridge University Press, The Pitt Building, Trumpington Street, Cambridge CB2 1RP, UK http://www.cup.cam.ac.uk

Panther, Klaus-Uwe and Radden, Gunter, eds,

Metonymy in Language and Thought

Inttoduction

Klaus-Uwe Panther and Gunter Radden 
Part I: Theoretical Aspects of metonymy Towards a

Theory of Metonymy

Gunter Radden and Zoltan Kovecses Speaking

and Thinking with Metonymy

Raymond W. Gibbs, Jr.

Metonymy and Conceptual Integration

Gilles Fauconnier and Mark Turner

Distinguishing Metonymy from Synecdoche

Ken-ichi Seto

Aspects caf Referential Metonymy

Beatrice Warren

Part II: Historical Aspects of Metonymy

Frame and Contiguity: On the Cognitive Bases of Metonymy and Certain Types of World Formation

Peter Koch

Co-presence and Succession: A Cognitive Typology of Metonymy Andreas Blank Metonymic Bridges in Model Shifts Louis Goossens

Metonymy and Onomastics Olaf Jakel

Part III: Case Studies of Metonymy

Grammatical Constraints on Metonymy: On the Rule of the Direct Object Richard

Waltereit

Putting Metonymy in its Place Paul Pauwels

Conversion as a Conceptual Metonymy of Event Schemata Rene Dirven

Opposition as a Metonymic Principle Christian Vosshagen

Metonymic Hierarchies: The Conceptualization of Stupidity in German Idiomtic Expressions

Kurt Feyaerts

The Potentiality for Actuality Metonymy in English and Hungarian Klaus-Uwe

Panther and Linda Thornburg

Part IV: Applications of Metonymy

'Mummy, I Ike being a sandwich": Metonymy in Language Acquisition Brigitte

Nerlich, David D. Clarke, Zazie Todd

Recontextualization of Metonymy in Narrative and the Case of Morrison's "Song of Salomon"

Anne Paukhurst 
List of Contributors

Subject index

Author index

Metonymy and metaphor index

ISBN 94-272-2356-4

John Benjamins Publishing V.B., Amsterdam 1999, p. 423

John Benjamins Publishing Co., P.O. Box 75577, 1070 Amsterdam, The Netherlands

$$
\text { Paton, Ray, ed., }
$$

\section{Computing with Biological Metaphors}

1 Introduction to Computing with Biological Metaphors R

Paton

Cells

2 From VLSI through Machine Models to Cellular Metabolism M Holcombe

3 Developing a Logical Tool to Analyse Biological Regulatory Networks R Thomas and D Thieffry

4 The Computational Machinery of the Living Cell G R Welch

5 Enzymes, Automata and Artificial Cells P Marijuan

6 The Molecular Computer C Winter

7 Computing Dendritic Growth P Hamilton

Tissues

8 The Brain as a Metaphor for Sixth Generation Computing M Arbib

9 ART3: Hierarchical Search using Chemical Transmitters in Self-organising Pattern Recognition Architectures

G Carpenter and S Grossberg

10 Fluid Neural Networks as a Model of Intelligent Biological Systems F Vertosick 
11 The Immune Learning Mechanisms: Reinforcement, Recruitment and their Applications

$\mathrm{H}$ Bersini and F Varela

12 Artificial Tissue Models W

R Stark

13 Streaming Tissue: The Tissue Automat G

Zajicek

Genetics and Evolution

14 Evolutionary Algorithms: Comparison of Approaches T

Baeck

15 Artificial Evolution and The Paradox of Sex R Collins

16 Both Wrightian and "Parasite" Peak Shifts Enhance Genetic Algorithm Performance B Sumida and W D Hamilton

17 Evolution of Emergent Cooperative Behaviour using Genetic Programming J Koza

18 An Evolutionary Approach to Designing Neural Networks A Bergman

Ecology

19 Free the Spirit of Evolutionary Computing: the Ecological Genetic Algorithm Approach Y Davidor

20 The Ecology of Computation B Huberman

21 An Ecological Analysis for Detecting Nods of the Head I Horswill

22 Socio-ecological Metaphors and Autonomous Agents G

Staniford

Theoretical and Conceptual Issues

23 The Importance of Selectionist Systems for Cognition B Manderick

24 Life-like Computing beyond the Machine Metaphor G Kampis

25 Nature's Machine: Mimesis, the Analogue Computer and the Rhetoric of Technology

J Nyce 
26 Computing with Biological Metaphors - some Conceptual Issues R Paton Indices

Author Index

Subject Index

Chapman and Hall, London 1994, p. 450

http://www.csc.liv.ac.uk/ biocomp/announce/an bi.html

\author{
Pulaczewska, Hanna
}

Aspects of Metaphor in Physics. Examples and Case Studies

Acknowledgements

Abbreviations

1. Introduction

Part One: The notion of metaphor and its relation to the discourse af physics

2. Approaches to metaphor: past and present

2.1 A short history of metaphor

2.2 Metaphor, an enemy of science: the early modem view

2.3 Metaphor, a friend of science: contemporary physicists on scientific knowledge

2.4 Current paradigms in research on metaphor in science

2.4.1 Linguist's metaphor, philosopher's metaphor

2.4.2 Philosopher metaphor

2.4.2.1 True models, objective mathematics?

2.4.2.2 Metaphor and physical theory

2.4.3 The view of metaphor as the linguistic dimension of a scientific analogy

2.4.4 Our appraach: a preliminary note

3. Identifying metaphor in physical science: sorts, functions, and related concepts

3.1 Metaphor and related concepts

3.1.1 Metaphor and model

3.1.1.1 Scientific model: an outline

3.1.1.2 Models and metaphors: affinities

3.1.1.3 Models and metaphors: distinctions

3.1.1.4 Metaphors turned models

3.1.1.5 Preliminary specification of conceptual metaphors of functions other than model-theoretical 


\subsubsection{Metaphor and false hypothesis}

3.1.2.1 Sort crossing and sort-trespassing

3.1.2.2 A definition of literal similarity?

3.1.2.3 Today's metaphors: yesterday's literal truths?

3.2 A working definition of metaphor

3.3 Sorts and functions of metaphor in physical discourse

3.3.1 Classifications ot metaphor in science

3.3.2 Sorts

3.3.2.1 Extended metaphor

3.3.2.2 Linguistic metaphor

3.3.2.3 Grammatical metaphor

3.3.3 Functions

3.3.3.1 Denomination

3.3.3.2 Theory and concept formation

3.3.3.3 Education

3.3.3.4 Style

3.3.3.5 Meta-theory

3.3.3.6 Sociology of scienfitic research

Part Two: Metaphors in Physics

4. Underlying metaphor of everyday thought in meta-theory and the concept formation of physics

4.1 Hypostasis

4.1.1 Nominalisation as metaphor

4.1.1.1 Ontological metaphor

4.1.1.2 Grammatical metaphor

4.1.1.3 Nominalisation of science and the scientific vision of reality

4.1.1.4 A physicist's critique: Bohm's "rheomode"

4.1.2 Hypostasis and the emergence of a scientific hypothesis: electric fluid

4.1.3 Hypostasis and the constitutive metaphor of optics: travelling light

4.2 Spatial metaphor

4.2.1 A general outline of spatial metaphor

4.2.1.1 The concept

4.2.1.2 Container metaphor

4.2.1.3 Motion and change

4.2.1.4 Orientational metaphor

4.2.2 Spatial metaphors in physics: where to find them

4.2.3 The metaphor of centrality and the Copemican revolution 4.2.3.1 The metaphor of centrality and its perceptual basis 
4.2.3.2 The central Sun and the metaphor

4.2.3.3 The metaphorical aspect of geodynamic hypothesis

4.2.4 Spatialisation of time

4.2.4.1 Space and time in general language

4.2.4.2 Time as movement: the experiential basis

4.2.4.3 Time flowing past, or the forward-sliding present?

4.2.4.4 "Flow of time" and the absolute theory of time

4.2.4.5 The paradox of time flow

4.2.4.6 Time as a receptacle of events and the absolute theory of time

4.2.4.7 Time flow, time receptacle, eternity, and classical determination

4.2.4.8 Time as the fourth dimension of space

4.2.4.9 An excursion: misconceiving time as space

4.2.4.10 The metaphor of space-time curvature

4.2.5 Container and orientational metaphors in quantum mechanics

4.2.5.1 Visual rendering of energy

4.2.5.2 Ranges and states: containers of physical processes

4.2.5.3 State as container in quantum mechanics

4.2.5.4 Bohr's model of atomic structure

4.2.5.5 Energy states of elementary particles

4.2.5.6 Band model (theory) of solids

4.2.5.7 "More is up" - in the energy potential field

4.2.5.8 Double/blended recipients of metaphorical denotations: potential wall, potential well potential barrier

4.2.6 Periodic changes

4.3 Animism and anthropomorphism

4.3.1 Animisms and anthrsropomorphisms as explanatory and articulatory devices in physical science

4.3.2 Spacial representation and selt-projection in the interpretative activity of physicists

4.3.3 The concept of force: Newtonian mechanics

4.3.4 Anthropomorphism and meta-theory: the secret of nature and associated concepts

4.4.1 The secrets of nature

4.3.4.2 Terra incognita - science as a voyage; science as a conquest

4.3.4.3 Science as venatio

5. World theories in meta-theory and the concept formation

5.1 The notion "world theory" and "world model"

5.2 World machine

5.2.1 The clock metaphor

5.2.2 The world as a working machine

5.2.3 Man and machine in information theory 
5.3 The world as a text

5.3.1 The book metaphor and scientific objectivity

5.3.1.1 The independene of the text

5.3.1.2 Understanding as non-involvement: the reduction of observing to seeing

5.3.2 Alphabet of nature

5.3.2.1 Mathematical alphabet and mechanical philosophy

5.3.2.2 Alphabet of nature and mathematical notation

5.3.3 Bacon's metaphor of two books

5.3.3.1 The dignity of natural knowledge

5.3.3.2 The "Authorised Version" of the Bible and Bacon's methodological thought

6. Stipulative reference extension

6.1 Stipulation of meaning: Huygens' notion of sound wave

6.2 Ivisible light and Roentgen's "invisible rays"

7. Assimilative metaphror

7.1 "Fluid" electricity

7.1.1 The rise and the concepts of the fluid theory

7.1.2 Re-definition of substance and the abandonment of the fluid theory

7.1.3 Flow of electricity and the electron theory

7.1.4 Flow of electricity as educational analogy

7.2 The concept of wave

7.2.1 The aether waves mechanical similarity of light and sound

7.2.2 The abandonment of the aether theory

7.2.3 Further development

7.3 Life stories of metaphor: from metaphorical to literal and literal to metaphorical

8. Theory-constitutive and educational metaphors

8.1 Constitutive metaphor: weves of probability

8.2 Educational metaphor: curvature of space

8.3 From explanation to rhetoric

9. Metaphor and style: "figures of speech" in the language of physics

9.1 The position of "figures uf speech" in the discourse of physics

9.2 The arrow of time

9.3 Heat death

9.4 Maxwell's demon

10. Transfer of denotation in the terminology of physics

10.1 Metaphors in generaf language and in the terminology of physics: the general language basis for the transfer of denotations

10.2 Types of transfer of denotations 
10.4 Fantasy-metaphor: the case of particle physics

10.5 "Mechanical work": underlying metaphor, world theory, scientific analogy

10.6 Catachresis and satellite metaphors

10.6.1 Miscellaneous spatial metaphors

10.6.2 Similarity in shape or size

10.6.2.1 Shape similarity

10.6.2.2 Size similarity

10.6.3 Animisim and anthropomorphisms

10.6.3.1 Donor domain: life and death

10.6.3.2 Animation by metaphorical projection of volition

10.6.3.3 Donor domain: family relationships

10.6.3.4 Donor domain: biological reproduction

10.6.3.5 Donor domain: psychophysiological phenomena

10.6.3.6 Donor subject: other physiological states, processes and agencies

10.6.3.7 Donor subject: other biological and ecological notions

10.6.3.8 Donor subject: supernatural beings

10.6.3.9 Donor domain: bodily structure

10.6.3.10 Donor domain: social values and behaviours

10.6.4 Donor domain: sense percepts

10.6.4.1 Donor domain: tactile perception

10.6.4.2 Donor domain: sensation of hot and cold

10.6.4.3 Donor domain: olfactory perception

10.6.4.4 Donor domain: auditory perception

10.6.4.5 Donor domain: visual perception

10.6.5 Hypostasis

10.6.6 Donor domain: utensils and instruments, recipient domain: physical instrument, ground of transfer: similarity of function

10.6.7 Donor domain: fire

10.6.8 Donor domain: fre-arms and shooting

10.6.9 Miscellanous donor and recipient subjects

10.7 Mathematical analogy . Thoughts and conclusion Inferences

BS3N 3-484-30407-3 ISSN 0344-6727

Max Niemeyer Verlng GmbH, Tubingen 1999, p. 301

Max Niemeyer Verlag GmbH, Postfach 2140, D-72011 Tubingen, Germany 
Radman, Zdravko, ed..

\section{Front a Metaphorical Point of View. A Multidisciplinary Approach to the Cognitive Content of Metaphor}

Preface

Introduction

Part One: A History of Philosophy Perspective

1. Tanehisa Otabe

From "Clothing" to "Organ of Reason": An Essay on the Theories of Metaphor in German Philosoghy in the Age of Enlightenment

2. Christiane Schildknecht

Experiments with Metaphors: On the Connection between Scientific Method and Literary Form in Francis Bacon

Part Two: A Semantic Perspective

3. Catherine Z. Elgin

Metaphor and Reference

4. Eva Feder Kittay

Metaphor as Rearranging the Furniture of the Mind: A Reply to Donald Davidson's "What Metaphors Mean"

5. Zoltan Kovecses

The "Container" Metaphor of Anger in English, Chinese, Japanese and Hungarian Part Three: A Cognitive Science Perspective

6. Earl R. MacCormac Neuronal Processes of Creative Metaphors

7. Eileen Cornell Way An Artificial Intelligence Approach to Models and Metaphors

8. Arthur I. Miller

Imagery and Metaphor: The Cognitive Science Connection

9. Zdravko Radman

How to Make Our Ideas Clear with Metaphors Part Four: A Philosophy of Science Perspective

10. Gerald Holton

Metaphors in Science and Education

11. Janet Martin Soskice and Rom Harre Metaphor in Science

12. Eleonora Montuschi

What is Wrong with Talking of Metaphors in Science?

13. Karin Knorr Cetina

Metaphors in the Scientific Laboratory: Why are they there and what dc they do? 
14. Mary Hesse

Models, Metaphors and Truth

Part Five: A Theological, Sociological and Political Perspective

15. Eman McMullin

The Motive for Metaphor

16. Jose M. Gonzalez Garcia

"Search for the Daimon", "Pact with the Devil" and "Fight of Gods": On

Some Metaphors of Goethe in Max Weber's Sociology

17. Francesca Rigotti

The House as Metaphor Notes on Contributors Acknowledgements Author Index Subject Index

ISBN 3-11-014554-5

Walter de Gruyter, Berlin 1995, p. 460

Radman, Zdravko

Metaphors: Figures of the Mind

Preface

Introduction

Part One: On Dead Literalness and Live Metaphorics

1. The Limits of Literalness

2. The Polysemic Chain of Meaning

3. Difficulties With Diagnosing the Death of a Metaphor Part

Two: On Fiction and Facts

4. The Metaphoric Measure Of Meaning in Science

5. How is Radically New Knowledge Possible?

Or: Bridging the New and the Old in a Metaphorical Way

6. How to Make Our Ideas Clear With Metaphors Part Three:

On the Body and the Mind

7. Toward a Metaphor-Body Problem

8. Artificial Intelligence and Natural Body Part Four: On

Metaphoriznig and World-Making

9. Key-Metaphors: A Case of Cross-Contextual Cognition

10. Of Mind, Metaphysics and Other Matters

11. Haw to Make Worlds With Metaphors 
12. Metaphorical Projections of Possible Worlds

Afterthoughts

Bibliography

Name Index

ISBN 0-7923-4356-5

Kluwer Academic Publishers, Dordrecht 1997, p. 186

Kluwer Academic Publishers, P.O. Box 17, 3300 AA Dordrecht, The Netherlands

\section{Rosenblatt, Paul C.}

\section{Metaphors of Family Systems Theory. Towards New Constructions}

Foreword by Kenneth J. Gergen

Acknowledgments

Introduction

Chapter 1. Metaphors and Theory

Chapter 2. The Metaphor of the Family as an Entity

Chapter 3. The Metaphor of System

Chapter 4. Metaphors of Family Boundaries

Chapter 5. Metaphors of Family Structure

Chapter 6. Metaphors of System Control

Chapter 7. Metaphors of Communication in Family Systems

Chapter 8. Metaphors of Family Systems Therapy

Chapter 9. Multiple Theoretical Metaphors and Multiple Realities

References

Name Index

Subject Index

ISBN 0-89862-321-9 (hbk) ISBN 1-57230-172-4 (pbk)

Guilford Press, New York 1994, p. 239

Guilford Press, 72 Spring Street, New York, NY 10012, USA

Ross, Don

Metaphor, Meaaning and Cognition

Why Metaphor?

1.1 Hume's Problem

1.2 Metaphor 
1.3 Naturalism, Functionalism and Eliminativism

1.4 Synopsis

Philosophers On Metaphor

2.1 Metaphor and Semantics

2.2 The "Traditional View" and Its Critics

2.3 The Comparison Theory Meaning and Metaphor

3.1 Of Chickens and Eggs

3.2 Davidson's Analysis of Meaning

3.3 Davidson on Metaphor

3.4 Metaphor and the Nature of a Semantic Theory

3.5 The Problem of Paraphrase The Ontology of Metaphor

4.1 Sentences and Utterances

4.2 Extensional Versus Psychological Individuation

4.3 Lakoff and Johnson Ontology

4.4 Prospects for a Sentential Realist Approach

4.5 Metaphor and Psychological Explanation Metaphor Explicated

5.1 The Asymmetry of Similarity

5.2 Literal vs. Metaphorical Comparisons

5.3 A Last Objection: The Conventionality of Vehicles Toward A Cognitive Theory of Metaphor Processing

6.1 On The Cognitive Role of Metaphor

6.2 Schema Theory and Neo-Interactionism

6.3 Metaphor and the Architecture of Cognition

6.4 Envoi Notes References Index of Names

ISBN 0-8204-2151-0

Peter Lang Publishing, New York 1993, p. 210

Rothbart, Daniel

Explaining the Growth of Scientific Knowledge: Metaphors, Models, and Meanings

Acknowledgements

Chapter 1: Introduction 
1. What is a Scientific Model ?

2. Responses to Critics

A. On the Necessity of Picturable Models

B. The Role of Analogy within Induction

C. On the Distinction between Validation and Discovery of Hypotheses

3. The Indispensability of Analogy and Metaphor within Science Chapter 2:

The Semanitcs of Scientific Metaphors

1. Semantic Theories of Metaphor

2. The Mechanics of Metaphor Feature Projection

3. Semantic Rules for Metaphors

4. The Dynamic Relationship Between Metaphoric and Literal Terms

5. Metaphor and Scientific Progress

6. Conclusion

Chapter 3: Analogical Modelling and Metaphoric Discourse in Science

1. Introduction

2. The Nineteenth Century Unification of Chemistries

3. What is the Conception of Analogy within Science ?

4. The Asymmetry of Scientific Analogy

5. Metaphoric Hypothesis Construction

6. Conclusion

Chapter 4: The Epistemology of a Spectrometer

1. Introduction

2. Instruments Designed as Replicas of Nature

3. Absorption Spectrometers

4. Overcoming the Skeptic's Noise

5. Data Structures

6. The Data/Phenomena Dichotomy by Bogen and Woodward

7. Towards an Experimental Realism

8. Conclusion

Chapter 5: The Nature of Scientific Prototype

1. Kuhn's Paradigm-Driven Science

2. What is a Prototype Model ?

3. Inter-theoretic Prototypes 
4. Prototype-Driven Metaphors

5. Conclusion

Chapter 6: Property, Symmetry, and Analogy

1. Introduction

2. Properties as Tendencies

3. Properties as Sorts

4. Van Fraassen on Symmetry Relations

Apendix: Computational Models of Analogical Reasoning References

Index

ISBN 0-7734-8721-2

The Edwin Mellen Press, Lewiston 1997, p.165

The Edwin Mellen Press, Box 450, Lewiston NY 14092, USA

Siegelman, Ellen Y.

Metaphor \& Meaning in Psychotherapy

Chapter 1. The Primacy of Metaphor

Case Example What is "Primary"?

Metaphor and the Origin of Language

Metaphor and the Origin of Thought

Dream Image versus Metaphoric Image

The Affective Primacy of Metaphor: Case Examples

Conclusion

Notes

Chapter 2. The Bodily Matrix of Metaphor

A Meditation on the Body

The Primacy and Specialness of Body Experience

The Container Schema

Body Experience as the Root of Psychological Metaphors

Image of the Body Container in Relation to Psychosomatic Symptoms

Symptom versus Metaphor

Transormation of Symptom into Metaphor: A Case Example Insight as

Connection through Body Affect 
Chapter 3. Exploring the Sources of Metaphors Clinically

Conventional or Authomatic Metaphors Enlivening the Conventional Metaphor Unearthing the Roots of a Conventional Metaphor A Novel Metaphor Becomes a Key Metaphor The Therapist's Role in Expanding the Metaphor

Chapter 4. Metaphors of the Self: Changes in the Course of Therapy

Metaphor and Its Consequences Howard K: From Flow-Chart to Atom in Motion Sylvia G: From Very Tight Shoes to Soft, Warm Shoes The Therapist's Role in Processing Key Metaphors

Chapter 5. Metaphor and Defense

Metaphor as Defense

Metaphors of Defense: Confinement versus Diffusion Spaciousness within Structure: What is Home?

Chapter 6. The Therapist's Metaphors

Interpreting by Means of Metaphor

Illustrating by Means of Metaphor

The Therapist Shares a Persistent Metaphoric Image

The Joint Elaboration of Metaphor by Patient and Therapist

Metaphoric Images and the Therapist's Empathic Understanding

The Metaphoric Relation to the Other: Transference Distortions and Empathic Identification

Chapter 7. Pitfalls in the Use of Metaphor

Overvaluing Metaphor Apart from Its Context Undervaluing Metaphor: The Therapist's Failure to Imagine Literalizing or "Freezing" Theoretical Metaphors

Chapter 8. Metaphors of the Therapeutic Encounter

Freud as a Metaphorist of the Therapeutic Process

Jung's Psychotherapeutic Space as Temenos, Circle, and Vessel 
Langs and Milner: Two Views of the Therapeutic Frame

Winnicott's Holding Environment and Potential Space

Chapter 9. The Symbolic Attitude

Jung's View of the Symbolic

Dimensions of the Symbolic Attitude: Awareness and Freedom from Arbitrariness

Failures of the Capacity to Symbolize

Patients Who Cannot Play

On Making It Safe to Play

The Symbolic Attitude and the Aesthetic Attitude

A Musical Metaphor of the Therapeutic Encounter: Resonance and Attunement References Index

ISBN 0-89862-431-2 (hbk) ISBN 0-89862-014-7 (pbk)

Guilford Press, New York 1990, p. 206

Guilford Press, 72 Spring Street, New York, NY 10012, USA

Steen, Gerard

Understanding Metaphor in Literature: An Empirical Approach

Preface

Publisher's acknowledgements

Author's acknowledgsments

Part one: Reader, text, context

Chapter 1: From metaphor as cognition to metaphor in discourse processing

1.1 The cognitive turn

1.2 Conceptual and linguistic metaphor: A structural view

1.3 Metaphor as non-literal analogical mapping: A processing view

1.4 Analogical mapping in discourse processing

1.5 Linguistic metaphor

1.6 Conclusion

Chapter 2: Metaphor in literary discourse processing

2.1 Literary criticism and the psychology of reading

2.2 Metaphor in literary discourse

2.3 Typically literary metaphors

2.4 Typically literary use of metaphors

2.5 Conclusion 
Chapter 3: Metaphor and literariness

3.1 Attention to metaphor

3.2 Effects of literary socialization and degree of metaphoricity

3.3 Effects of discourse context

3.4 Conclusion

Part two: Processes

Chapter 4: Aspects of metaphor processing

4.1 Aspects of text processing

4.2 Metaphor in text processing

4.3 Metaphor in literary text processing Chapter 5: Metaphor processing in thinking out loud

5.1 Thinking out loud in the empirical study of literature

5.2 Pilot studies in thinking out loud

5.3 Conclusion

Chapter 6: Metaphor processing in literature and journalism

6.1 Introduction

6.2 Method

6.3 Results

6.4 Discussion

6.5 Additional analyses: textual interest and reader performance in thinkin out loud

6.6 Conclusion

Part three: Properties

Chapter 7: Dimensions ot metaphor

7.1 Metaphors and types of discourse

7.2 The role of the text

7.3 Dimensions af metaphor

7.4 Metaphors in science and literature

7.5 Poetic and constructed metaphors

7.6 Conclusion: literary and non-literary metaphors Chapter 8: Literary and journalistic metaphors

8.1 Dimensions and properties of 96 English-language metaphors

8.2 A follow-up study with 164 Dutch metaphors

8.3 Conclusion

Chapter 9: Properties and processes

9.1 Metaphor properties

9.2 Properties and processes in underlining

9.3 Properties and processes in thinking aut loud

o 4 Conclusion 
Conclusion

Chapter 10: Understanding metaphor in literature

Bibliography

Name Index

Subject Index

ISBN 0-582-21715-6 ISBN 0-582-10118-2

Longman Group, London 1994, p. 243

Longmnan Group Limited, Longman House, Burnnt Mill, Harlow, Essex CM20 2JE, England

Steinhart, Eric Charles

The Logic of Metaphor: Analogous Parts of Possible Words

\section{INTRODUCTION}

1 Metaphors and Logic

2 Metaphor and Possible Worlds Semantics

2.1 Logical Truth-Conditions for Metaphors

2.2 Analogical Access and Counterparts 2 Analogical

Counterparts

3.1 Hobbes's Analogy A STATE IS AN ORGANISM

3.2 Swanson's Analogy THE CELL IS A FACTORY Theory-Constitutive Metaphors

4.1 Some Different Kinds of Metaphors

4.2 Explication of Theory-Constitutive Metaphors

4.3 Examples of Theory-Constitutive Metaphors

4.4 Analogical Inferences to Existence 5 Analyzing Metaphors

5.1 Literal and Metaphorical Meanings

5.2 Meanings and Contexts

5.3 Stories as Contexts for Metaphors

54 Descriptions as Contexts for Metaphors

5.5 Shared Syntactical Patterns of Descriptions

5.6 Shared Objective Patterns of Situations

57 Analogical Truth-Conditions for Metaphors

5.7.1 "Juliet is the sun"

5.7.2 "Her lips are cherries"

5.7.3 "Sally is a block of ice"

6. Philosophical Application of the Computer 
Appendix 1.1: Sample Metaphorical Texts

1. Augustine: Memory as Stomach

2. Newton: Sound and Light

3. Kant: Human Action

4. Kant: The State

5. Schopenhauer: Experience

Appendix 1.2: Analogical Inferences to Existence

1. Argument by Analogy for Other Minds

2. Argument by Analogy for the Existence of God

3. Argument by Analogy for Imaginary Boolean Values

4. Argument by Analogy for the Null Individual

5. Argument by Analogy for Luminiferous Ether

\section{LANGUAGE}

1. Introduction

2. Languages

2.1 The Internal and External Languages

2.2 Surface Structures and Deep Structures

2.3 Literal and Metaphorical Meanings

2.4 Context and Interpretation

3. The Grammar of Metaphor

3.1 Rewrite Rules

3.2 Grammatical Classes of Metaphors

3.3 Metaphorical Word-Combinations

3.4 Marking Word-Combinations as Literal or Metaphorical

3.5 Rewrite Rules for Making Metaphors

4. Propositions

4.1 The Predicate Calculus

4.2 Adding Thematic Roles to Propositions

4.3 Adding Indexes to Propositions

4.4 Logical Space and Situations

4.5 Analogous Situations in Logical Space

5. Propositions as Networks

5.1 Atomic Propositions as Networks

5.2 Reference and Truth for Atomic Propositions

5.3 Molecular Propositions as Networks

5.4 Descriptions of Situations

6. Conclusion 
Appendix 2.1: Semantics

1. The Extended Predicate Calculus

1.1 Events and Occurrences

1.2 Arguments for Occurrences

1.3 Symbols in the Extended Predicate Calculus

1.4 Relations in the Extended Predicate Calculus

1.5 Models for the Extended Predicate Calculus

1.6 Sample Simple Logical Space

2. Situations

2.1 Situations are Collections of Occurrences

2.2 Sample Logical Space and Situation

2.3 Graphs of Situations

3. Semantics for the Extended Predicate Calculus

3.1 Meaning Functions and Variable Assignments

3.2 Truth-Values for Atomic Propositions

3.3 Atomic Proposition Correspond to States-of-Affairs

3.4 Truth-Values for Molecular Propositions

3.5 Truth-Values for Quantified Propositions

3.6 Truth-Values for Modal Propositions

\section{CONCEPTUAL STRUCTURES}

1. Introduction

2. The Network of Concepts

3. The Taxonomic Hierarchy of Types

4. The Mereological Hierarchy of Types

5. Taxonomic Hierarchy of Processes

6. Contrastive Structures

7. Symmetries in Networks

8. Rules and Lexical Entailments

9. Conceptual Fields

9.1 Fields are Clusters of Concepts

9.2 The Utility of Conceptual Fields

9.3 Similarity Fields and Topical Fields

9.4 How Metaphors Depend on Conceptual Fields

10. Conclusion

Appendix 3.1: Sample Descriptions

1. Descriptions as Input to NETMET

2. Methods for Making Input for NETMET

3. NFTMFT's Concentual Network 
4. Descriptions and their Textual Origins

5. Sample Descriptions

5.1 The Description of Human Reproduction

5.2 The Description of Intellectual Creativity

5.3 The Description of Memory

5.4 The Description of the Wax Tablet

5.5 The Description of the Aviary

5.6 The Description of the Atom

5.7 The Description of the Solar System

\section{ANALOGY}

1. Introduction

2. Towards a Formal Theory of Analogy

2.1 Formal Definition of Analogy

2.2 Subsymbolic Analogies

2.3 Synesthetic Analogies

3. The Stages of Analogical Inference

4. Analogical Access

4.1 The Purpose of the Access Phase

4.2 Analogical Access as a Kind of Plausible Inference

5. Analog Retrieval by Constraint Satisfaction

5.1 Plausible Inference via Constraint-Satisfaction in ARCS

5.2 The Network in ARCS

5.3 Arguments Used to Build an ARCS Network

5.4 Running an ARCS Network

5.5 Evaluation of ARCS

6. The Access Phase in NETMET

6.1 Generating the Target Field

6.2 Finding the Indexes in the Target

6.3 Collecting Target Predicates

6.4 Finding Candidate Source Indexes

6.5 Finding Candidate Source Fields

7. Analogical Mapping

7.1 The Analogical Mapping Function

7.2 Analogical Mapping as a Kind of Plausible Inference

7.3 Computing the Analogical Mapping Function

8. Analogical Mapping by Constraint Satisfaction

8.1 Generating Match Hypotheses

8.2 Relations between Match Hypotheses

8.3 Finding the Analogical Mapping Relation

8.4 Running the Hypotheses Network 
9. Difficulties with Proportional Analogy

10. A Structural Model of Analogical Mapping

10.1 Structural Principles for Analogical Mapping

10.2 Principles for Generating a Hypothesis Network

10.2.1 The Principle of Proportional Analogy

10.2.2 The Principle of Extension to Contrast Sets

10.2.3 The Principle of Mereological Analogy

10.2.4 The Principle of Extension to Properties

10.2.5 The Principle of Extension to Covering Sets

10.2.6 The Principle of Mutual Inconsistency

10.3 Supplying External Activation to NETMET Hypothesis Nets

10.4 Running NETMET Hypothesis Nets to Convergence

10.5 Extracting a One-to-One Map

11. Conclusion

\section{ANALOGICAL TRANSFERENCE}

1. Introduction

2. Analogical Transference

2.1 The Mechanism of Analogical Transference

2.2 The Analogical Transference Operator

2.3 Adding Novel Propositions to the Target

3. Subsymbolic Analogical Transference

4. An Extended Example of Analogical Transference

5. Rules for Analogical Transference

5.1 The Process of Analogical Transference

5.2 Transference of Source Properties

5.3 Transference of Source Features

5.4 Transference of Source Relations and Processes

5.5 Transference of Source Rules

6. Analogical Transference and Induction

6.1 Inductive Arguments

6.2 Syntactic Form of Inductive Arguments by Similarity

6.3 Syntactic Form of Inductive Arguments by Analogy

6.4 The Problem of Inductive Support

6.5 Determination in Inductive Arguments by Similarity

6.6 Determination in Inductive Arguments by Analogy

6.7 Inductive Support for Analogically Transferred Propositions

7. Perfect Analogies

8. Self-Mirroring Universes

8.1 Analogous Situations within Possible Worlds 

8.2 Black's Dual Universe
8.3 Infinite Two-Way Recurrence
8.4 Royce's Perfect Map of England 9. Conclusion

Appendix 5.1: Examples of Analogical Transference

1. Transference in the SOCRATES IS A MIDWIFE Analogy

2. Transference in the MEMORY IS A WAX TABLET Analogy

3. Transference in the MEMORY IS AN AVIARY Analogy

\section{METAPHORICAL COMMUNICATION}

1. Introduction

2. Generating Metaphorical Utterances

\subsection{From Analogies to Metaphors}

2.2 Rules for Generating Metaphors

2.2.1 Noun-Identification Metaphors

2.2.2 Noun-Predication Metaphors

2.2.3 Noun-Identification Metaphors with Contrary Adjectives

2.2.4 Noun-Identification Metaphors with Literally Predicated Adjectives

2.2.5 Noun-Identification Metaphors with Functional Genitives

2.2.6 Noun-Identification Metaphors with Mereological Genitives

2.2.7 Simple Adjective-Predication Metaphors

2.2.8 Complex Adjective-Predication Metaphors

2.2.9 Verb-Predication Metaphors

2.2.10 Verb-Predication Metaphors with Genitives

3. From Metaphors to Analogies

3.1 Literal and Metaphorical Interpretations

3.2 Using the Core Schema to Interpret Metaphors

3.3 Sample Algorithms for Filling the Core Schema

3.3.1 Verb-Predication Metaphors

3.3.2 Noun-Identification Metaphors with Genitive Phrases

3.3.3 Noun-Identification Metaphors

3.3.4 Noun-Predication Metaphors

3.4 From the Core Schema to its Analogy

3.5 An Extended Application of the Core Schema

3.6 Finding the Analogies in Larger Texts

4. Conclusion

\section{ANALOGY AND TRUTH}

1. Introduction

2. Truth-Conditions for Analogies 


\subsection{Truthful Metaphors based on Truthful Analogies \\ 2.2 Analogy Completion: The Miller Analogies Test \\ 2.3 Truth-Conditions for Analogies}

3. Logical Paraphrases for Metaphors

3.1 Literal and Metaphorical Meanings

3.2 Simple Analogical Truth-Conditions

3.2.1 Noun-Identifications

3.2.2 Noun-Identifications with Prepositional Phrases

3.2.3 Verb-Predications

3.3 Trivial Satisfactions of Analogical Truth-Conditions

4. Rules for Assigning Truth-Values to Metaphors

4.1 Metaphor and Modality

4.2 Truth-Conditions based on Analogical Counterparts

4.2.1 Individual-Individual Identification

4.2.2 Sortal-Sortal Identification

4.2.3 Individual-Sortal Predication

4.2.4 Individual-Property Predication

4.2.5 Property-Property Predication

4.2.6 Source Relation with Target Arguments

4.2.7 Source Relation with Target and Source Arguments

4.3 Metaphorical Existence Problems

5. Metaphorical Identity is Relative Indiscemibility

5.1 Relative Indiscemibility

5.2 Analogy Metaphors as Relative Indiscemibilities

5.3 Similarity Metaphors as Relative Indiscemibilities

6. Conclusion

-.ppendix 7.1: Intensional Semantics for Metaphors

1. Introduction

2. Logical Space

3. Permutations of Particulars

4. Equivalence of Situations

5. Isomorphism of Situations

6. Analogy of Situations

7. Intensional Semantics for Analogies

8. Analogical Truth-Conditions for Metaphors

9. Functions from Situation-Pairs to Truth-Values

\section{METAPHOR AND INFERENCE}

1 Introduction 2. Metaphor and Inference 
2.1 Forward and Backward Inference

2.2 Inference in Metaphor Interpretation

2.3 Inference to the Best Literal Paraphrase

2.4 Inference in Metaphor Justification

3. Metaphor Justification

3.1 Metaphors as Hypotheses

3.2 Abductive Logics for (Dis)confirmation of Hypotheses

3.3 Syntactic and Semantic Constraints on Abductive Arguments

3.4 Abductive Arguments for Metaphorical Propositions

3.5 The Transference of Source (In)Coherence Relations

3.6 Cognitive Meaningfulness for Metaphors

4. Metaphor Interpretation

4.1 The Black-Tourangeau Metaphor Interpretation Method

4.2 Computation of Implication Complexes

4.3 Transference by Deduction \& Abduction

4.4 A Historical Example of Black's Procedure

4.5 Entailments of Verb-Predication Metaphors

4.6 Common Abstract Entailments and Logical Paraphrases

5. Conclusion

IX. LEXICAL MEANINGS

1. Introduction

2. Definitions for Metaphorical Predicates

2.1 Operational Definitions

2.2 Open Lists of Partial Definitions

2.3 Definitions for Concepts in Natural Lexicons

2.4 From Approximate Meanings to New Definitions

3. Metaphors Based on Perfect Analogies

4. Inference to the Best Definition

4.1 Metaphor Interpretation via Common Abstract Entailments

4.2 Metaphor Interpretation via Implication and Explanation

5. Informative Truth-Conditions

5.1 From Counterparts to Meaning Postulates

5.2 Truth-Conditions and Confirmation-Conditions for Metaphors

6. Metaphors Based on Imperfect Analogies

6.1 First Application of the Deduction-Abduction Technique

6.2 Second Application of the Deduction-Abduction Technique

7 Conclusion

X. CONCLUSION

XI. REFERENCES 
Hardbound, ISBN 0-7923-7004-X

Kluwer Academic Publishers, Dordrecht 2001, 264 pp.

Stellardi, Giuseppe

Heidegger and Derrida on Philosophy and Metaphor: Imperfect Thought

Introduction

Philosophy and metaphor: the dimensions of a problem

A. Field

1. Philosophical theories of metaphor

2. Usage of metaphors in philosophy

3. Relationship between metaphor and philosophy

B. Motives

1. Philosophy before metaphor

2. Metaphor as philosophy's problem

C. Directions

1. Theory of metaphor

2. Theory of philosophical discourse

3. Heidegger, Derrida: imperfect thoughts Notes

I. On metaphor

Preliminary questions

A. Beyond the traditional model

1. Labels and metaphors

2. Towards a description of metaphor

B. The mechanism of metaphor

1. Definitions

2. The trait

3. Text, context, reader

4. The "other" of metaphor Notes

II. Derrida: the catastrophe of metaphor

A. The Ricoeur-Derrida debate

1. Philosophy within metaphor?

2. The living metaphor

3. The retreat anci the catastrophe

4. Some questions

B. Metaphors and indecidables

1. Cumbersome metaphors

2. Derrida's operations

3. Impossible foundations 
Conclusion?

Notes

III. Heidegger: metaphors that hurt

A. Position of the problem and inatial questions

B. Delimitating the field

a) Operative notion of metaphor

b) Sample of texts

C. Metaphor in Unterwegs zur sprache

1. Heidegger and metaphor

2. Grayness

3. Suffering

4. Control

D. The structure and function of Heidegger's metaphor

5. The structure of "Die Sprache"
a) Textual articulations
b) Logico-rhetarical resources
c) Metaphors
d) The poem

6. Metaphor and suffering: the threshold

7. Silence and the word

E. Thought of difference

1. Difference and analogy: the trait

2. Poetry and thought

3. Heidegger's operation

Notes

4. Grayness or bltss?

IV. Of philosophy

A. philosophy among the modes of discourse

1. Modes of discourse

2. Analysis of variables

3. Models of discourse and metaphor

4. Modes of discourse and ethics

5. Modes of disecourse and truth

B. Philosophical discourse

1. Philosophical truth and ethics

2. Forthcoming thought

3. Non-representational thought

4. Thought as productive function

5. Heidegger's reader

6. Etymology, quotation marks, commas, rhetorical question

7. Philosophy and metaphor 
C. Strategies of deconstruction, or the endless death of theory

1. Two metaphors

2. Structualism nad deconstrction

3. Force and form

4. Metaphor, Theory and supertheory

5. Fidelity and transgression

6. Life and death Notes

In place of a conclusion

Notes

Index

Bibliography

ISBN 1-57392-824-0

Humanities Books, Amherst 2000, p. 272

Hurmanites Books, 59 John Glenn Drive, Amherst, New York 14225-2197 Email

pontano@aol.com

Stern, Josef

\section{Metaphor in Context}

Preface

Sources

Chapter 1: Metaphorical Competence

I. Knowledge that Metaphor, Knowledge of Metaphor, and Knowledge by Metaphor U. Metaphor and Context-dependence: A Quick Tour of the Argument EU. Methodological Preliminaries

Chapter 2: From Metaphorical Use to Metaphorical Meaning I. Maning vs. Use

U. If Literal Meaning, Why Not Metaphorical Meaning ?

III. Metaphorical/literal Dependence I: Davidson's Causal Explanation

IV. Metaphorical/literal Dependence I: Davidson on Referential Definite

Descriptions,

V. Malapropisms, and Metaphor

VI The Autonomy of Meaning and Metaphor VII s a

Semantic Theory of Metaphor Possible? 
Chapter 3: Themes from Demonstratives

I. Some Prehistory

II. Character and Content

III. Direct Reference: Singular and Predicative

IV. Indexicals and the Parametric Determination of Their Referents

V. Dthat-descriptions and Complete Demonstratives

VI. Demonstrations and Presentations

VII. Dthat-descriptions

Chapter 4: Knowledge of Metaphor

I. The Context of a Metaphor: Presuppositions

II. Presuppositions, Belief, Pretense, and Presuppositions

III. Utterance-presuppositions and Metaphor

IV. Is Knowledge of Metaphorical Character Really Semantic?

Chapter 5: Knowledge by Metaphorical Content

I. A History of Similarity in Metaphor

II. Exemplification

III. Metaphors of Exemplification

IV. Thematic and Inductive Networks

V. Lakoff et al. On Metaphor

VI. Exemplification, Ctachresis, and De Re Knowledge by Metaphor

Chapter 6: Metaphorical Character and Metaphorical Meaning

I. Knowledge of 'Mthaf

II. Metaphorical Incompetence

III. The Interpretation vs. Evaluation of a Metaphor

IV. Metaphorical Meaning

V. Metaphor and Indirect Speech Acts

VI. Nominative Metaphors

VII. Metaphor and Simile

VIII. Is There One Natural Kind of Trope ?

IX. Three Semantic Theories of Metaphor: A Comparison

X. Objections and Replies

Chapter 7: Knowledge by Metaphorical Character

I. Marie's Problem-and Ours

II. The Rise and Fall of Literal Paraphrasability 
III. The Endlessness of Metaphorical Interpretation

IV. Metaphorical Mode of Presentation

V. Surprise

VI. Metaphorical Perspective

VII. Metaphor and Seeing-as

VIII. Metaphor and Pictures I

IX. Metaphor and Pictures II

X. Belief in Metaphor: Marie Again

XI. The Moral of the Story

Chapter 8: From the Metaphorical to the Literal

I. Nonlinguistic Metaphors

II. Historical and Contemporary Notions of the Literal

III. Dead Metaphors

IV. Literal Interpretations as Context-independent Interpretations

Notes

References

Index

ISBN 0-262-19439-2

The MIT Press, Cambridge, MA 2000

The MIT Press, Massachusetts Institute of Technology, Cambridge MA 02142, USA http://mitpress.mit.edu

Stoellger, Philipp

Metapher and Lebenswelt: Hans Blumenbergs Metaphorologie als Lebenswelthermeneutik und ihr religionsphanomenologischer Horizont

I. Einleitung

II. Hans Blumenbergs Metaphorologie

A. Theologische Anfange

Der Ursprung "urspriinglichen Seinsverstehens" im Christentum und die Anfange der Metaphorologie

B. Das erste Paradigma der Metaphorologie Licht als Metapher der Wahrheit

C. Paradigmen zu einer Metaphorologie 

D. Die Unmóglichkeit einer Metaphorologie Derridas Kritik jeder Metaphorologie ais Metaphysik
E. Ausweitung der Metaphorologie zur Lebensweltphanomenologie

III. Remetaphorisierung der Theologie und Retheologisierung der Metaphorologie
A. Fabelhafter Stil: Kulturgenese, Menschwerdung und Entstehung der Religion aus imaginativer Nachdenklichkeit
B. Rettung der Unbestimmtheit ais Interpretationsspielraum
C. Die cusanische Kunst der Vermutung ais imaginativer Umgang mi: Unbestimmtheit
D. Blumenbergs Arbeit an der "Wiederkehr Gottes" Die Vorgeschichte der Matthauspassion
E. Jtingels Arbeit an der Sagbarkeit Gottes in der Neuzeit
F. Die "Wiederkehr Gottes" in der Matthauspassion Phanomenologische Variation der Passion im Horizont der Neuzeit
Literaturverzeichnis
Seitenkonkordanz der 1. und 2. Auflage der "Paradigmen"
Metaphem- und Begriffsregister

Namensregister

ISBN 3-16-147302-7

Mohr Siebeck, Tubingen 2000, p.584

Mohr Siebeck, Postfach 2040, D-72010 Tubingen, Germany

http://www.mohr.de

\author{
Streib, Heinz \\ Hermeneutics of Metaphor, \\ Symbol and Narrative in Faith Development Theory
}

Preface

List of figures 0 . Introduction

PART ONE: THE HERMENUTICS OF FAITH DEVELOPEMEN THEORY A CHARACTERIZATION OF FOWLER'S THEORY.

1. The Concept of 'Faith' and 'Faith Development'

1.1. The Demarcation of the Definition: 'Faith' and 'Belief' 1.1.1. The 'Faith' - 'Belief Distinction in Fowler's Work

1.1.2. Interpretation and Evaluation of Fowler's 'Faith' - 'Belief' Distinction 
1.2. The Key Definition: 'Faith' as "Constitutive-Knowing”

1.3. The Multi-Dimensionality of 'Faith'

1.3.1. Seven Aspects of 'Faith'

1.3.2. The Three Dimensions of 'Faith'

1.3.3. Four Patterns of Interaction

1.3.4. Six Components of the Dynamics of Adult 'Faith'

1.3.5. Concluding Remark

2. 'Faith', 'Faith Development', and the Structuring Power of Content

2.1. The Significance of Images, Symbols, and Narratives for 'Faith' and 'Faith Development'

2.2. The 'Tension' between Structure and Content

3. Hermeneutics and Methodology in Faith Development Research

3.1. Interviewing \& Coding as "an Exercise in Hermeneutics"

3.1.1 Reconstruction and Multi-Dimensionality in Faith Development Research

3.1.2 Structural Reconstruction and the Contents in Faith Development Research

3.1.3 Taking the Narrative Coherence of the Life History in Faith into Account

4.2. The Rootedness of Faith Development Research in the Hermeneutics of Developmental Psychology

4. Theological Hermeneutics in Faith Development Theory

4.1 Faith Development Theory's Rootedness in Theological Hermeneutics and the Symbolic Character of 'Faith'

4.2. Re-interpretation of Faith Development Theory in Terms of Theological Hermeneutics

4.3 Conclusion and Synopsis.

PART TWO: RICOEUR'S HERMENUTICAL PERSPECTIVE - IN REGARD TO ITS CONTRIBUTIONS TO FAITH DEVELOPMENT THEORY

5. Self Understanding, Personhood and Our Dependence on Mediation

5.1. The Insufficiency of the subject and the 'Detour'

5.2. Mediation to the 'World' to Truth, to Reality

5.2.1. Mediation through Language

5.2.2. Symbol, Symbolic Truth and Naivete

5.2.3. Metaphor, Metaphorical Truth and the 'World of the Text'

5.2.4. Narrative and Narrative Truth

6. The Gift of the Text and the Constitution of the Person

6.1. Self Understanding as Gift

6.1.1. The Ontological Signification of Hermeneutics

612 Accimilation and Danantration 

6.1.3. Receptivity and Person-Constitution
6.1.4. 'Listening' and the Constitution of Faith

6.2. Does Ricoeur Propose a Model of Development?

6.2.1. The Model of the Text and the Idea of Development

6.2.2. Life History as "a Cloth Woven of Stories Told"

7. The Propasal for Social Scientific Methodology: The Model of the Text

7.1. Ricour's Acceptance of the Hermeneutical Turn: Agreement with and Difference from Habermas

7.1.1. Surpassing Dilthey's Aporetic Dichotomy

7.1.2. The Multi-Dimensionality of Interpretation

7.2. The Plurivocity of Meanings

7.3. Fixation and Reconstruction

7.4. A Method of Reading: From Understanding to Explanation

7.5. A Method of Reading: From Explanatian to Understanding

\section{PART THREE: TOWARD A CONTEXTUALIST MODEL FOR FAITH DEVELOPMENT THEORY}

Introduction: The Limits and Strengths of both Fowler and Ricoeur

8. Toward a Contextualist Model of Faith

8.1. Metaphor, Symbol, Narrative and the Constitution of Faith

8.1.1. 'Listening' to Symbol Representations as the Ground of Faith 8.1.2 The Narrative Constitution of Faith

8.2. The Concept of Faith Between Cunstitutive-Knowing and Symbolic- Narrative Constitution - Faith Development Theory Recoonsidere

8.2.1. The Structural-Developmental Paradigm: Valuable, but Insufficient

8.2.2. Con-text-utalist "Growing Edges" in Faith Development Theory

8.2.3. Contours and Dimensions of Further Developments

9. Toward a Con-text-ualist Model of Faith Development

9.1. Development as Multi-Dimensional Interplay of Contexts: A Hermeneutical Perspective

9.2. The Structural-Developmental Paradigm: Valuable, but Insufficient

9.3. Between Structural-Developmental Paradigm and Structuring Power of the Contents: Faith Development Theory Reconsidered

9.4. Faith Development - A Con-text-ualist Model

9.4.1. Faith Development and the Structuring Power of the Con-texts

9.4.2. Faith Development and the Structuring Power of the Self-Self Context

9.4.3. Contours and Dimensins of Further Developments

10. Toward a Con-text-ualist Model of Faith Development Research

10.1. From Explanation to Understanding: Faith Development Research in the Interpretive Turn 
10.2. A Further Step toward Understanding: Accounting for Contextual Richness, and Responsiveness

10.3. From Understanding to Explanation: Communicative Reconstruction and Life Narrative

11.3.1. Communicative Reconstruction

10.3.2. Reconstruction of Life Narrative

Conclusion

References

ISBN 3-631-43029-9

Verlag Peter Lang GmbH, Frankfurt am Main 1991, p. 237

Tilley, Christopher

Metaphor and material culture

List of Plates

List of Figures

Lists of Tables

Preface

PART I METAPHOR ABD THE CONSTITUTION OF THE WORLD

1. Metaphor in Language, Thought, and Culture

2. Solid Metaphor: The Analysis of Material Forms PART II

TEXT, ARTEFACT, ART

Introduction

3 Frozen Metaphor: Megaliths in Texts

4 The Metaphorical Transformations of Wala Canoes

5 Body Metaphors in Southern Scandinavian Rock Art.

PART III LANDSCAPES AND A SENSE OF PLACE Introduction

6 The Beach in the Sky

7 Performing Culture in the Global Village

8 Conclusions References Index

ISBN 0-631-19202-6 (alk. paper). - ISBN 0-631-19203-4 (pbk.: all. paper)

Blackwell Publishers, Oxford 1999, p. 298

Blackwell Publishers Ltd 108 Cowley Road, Oxford 0X4 1JF, UK 
Van Noppen, Jean-Pierre, ed.,

Metaphor II: A Classified Bibliography of Publications 1985 to 1990

Preface

Alphabetically Classified Bibliography

Indexes

Index of Disciplines

Index of Tenors, Vehicles and Semantic Fields

Theoretical Notions and Uses of Metaphor Index of

Names

Supplement: Additional Titles

ISBN 90-272-3746-8

John Benjamins B.V., Amsterdam 1990, p. 350

John Benjamins Publishing Co., P.O. Box 75577, 1070 Amstrdam, The Netherlands

Way, Eileen Cornell

Knowledge Representation and Metaphor

Series Preface

Preface

List of figures

1. The Literal and Metaphoric

Introduction

Historical Accounts of Metaphor The Pervasivenes of Metaphor

Metaphors Extend Our Conceptual Framework

Types of Figurative Speech Aspects of Metaphor

The Truth Status of Metaphor

Identifying Metaphor Literal Language

Claims that All Language is Metaphoric The Dynamic Type Hierarchy Accuunt of Literal and Figurative Lauguage Methodological Considerations Notes

2. View of Metaphor

Terminology 
Theories of Methapor Emotive Theories

Problems with Emotive and Tension Views The

Substitution Approach The Comparison Theory

Metaphor as Analogy

Problems with the Substitution and Comparison Views The

Controversion Theory The Anomaly Theory

Problems with the Controversion and Anomaly Views The

Interaction View

Some Implications of the Interaction View Problem with the

Interaction View

Psychological Evidence The Two-Stage

Theory Reaction-Time Studies

Studies Confirming The Two-Stage Hypothesis Refutations

of the Two- Stage Theory Literal and Metaphoric Processing is Similar The Truncation Hypothesis The Prior Association Hypothesis Domain Interation

Notes

3. Knowledge Representation

Introduction

Issues in Knowledge Representation

Expressive Adequacy and Notational Efficacy Semantics

Primitives

Semantic Primitives

Case Grammars

Knowledge Acquisition

Procedural vs. Declarative Knowledge

Meta-Knowledge

Reasonig Strategies

Non-Monotonic Reasonig

The Frame Problem

Logic and Knowledge Retsresentation

First-Order Logic Representing

Knowlede Criticisms 
Inference

Problems with Resolution Proofs

Difficulties with Deduction

The Advantages of Being Scruffy

Conclusion Notes

4. Representation Schemes and Conceptual Graphs

Introduction

Semantic Networks

Semantic Nets and Logic Canceptual

Dependency Frames and Scripts

Frames and Logic

Conceptual Graph Theory

Canceptual Graph

Linear Form

Kinds of Reference

Conceptual Relations

Type Hierarchy

Roles Types and Natural Types

Type Lattice

Formation Rules

Generalization and Specialization

Schemata

Prototypes

Defining Types

Context Boxes

Formal Deduction

Notes

5. The Dynamic Type Hierarchy Theory of Metaphor Introduction

Requirements for a Theory of Metaphor

Conceptual Graphs for Metaphor The DTH

View of Metaphor

Context Masks

Creation of Supertypes in Commnon

Interaction View Revisited

System of Cammonplaces

Not Equivalent to Literal Paraphrases

Metaphor Creates Similarity

Metaphor Filters 
Meaning Shifts

Examples

The Car is Thirsty An Example from Science

Conclusion

Notes

6. Computatianal Approaches to Metaphor

Introduction

Problems from the Comparison View The Problem of

a Fictional Subject Attribute Inequality

The Asymetry of Metaphor The Problem of Feature Selection

Salience Imbalance

The Analogy Approach to Metaphor

Analogy is More than Just Similarity of From Metaphors

Generate Analogies

Top-Down Approach Using General Metaphors

Structure Mapping

Domain Interaction

Metaphor and Fuzzy Sets

Conclusion

Notes

7. The Nature and Structure of Semantic Hierarchies

Introduction

Historical Account of the Relation between Concepts Frege

Carnap Quine

Artificial Intelligence

Examples of Why Class Inclusion Won't Work The

Determinate-Determinable Relation

Why Deteminate-Determinable is not Genus-Species

Searle's Conditions

Inheritance

The Global Structure of Tangled Hierarchies

Conclusion

Notes

5 Language Games. Open Texture and Family Resemblances

Introduction

Ideal Language Philosophy 
Analytic-Synthetic Distinction, Necessary and Sufficient Conditions

Artificial Intelligence and Ideal Language

Ordinary Language Philosophy Family Reseamblance

Theory Criticism of Natural Language Processing

Open Texture

Reply to Odell

Prototype Theory

Problems with Prototype Theory

Problems with Family Resemblance Theory

An Interpretation of Family Resemblance

DTH, Family Resemblance and Open Texture Tools and Eating Utensils

The 'Slab' Language-Game Revsited Open Texture in Science Nominalism and Realism

Conclusion

Notes

9. Programming the Dynamic Type Hierarchy

Introduction

The Semantic Interpreter: Cgen The Data Structures

Concepts and Relation Contexts

Lambda Abstractions Semantic Network Lexicon

The Cgen Algorithm

Syntax Determines Join Starting Points

The Dynamic Type Hierarchy On-Line Dictionary

Masking the Hierarchy Creation of New

Determinables in Common Procedure for

Interpreting Metaphors Abstracting Lambda

Definitions Adaptive Type Nodes Identifying

Metaphors

Bibliography

Author Index

Subject Index 
ISBN 0-7923-1005-5

Kluwer Academic Publishers, Dordrecht 1991, p. 271

Kluwer Academic Publisher, P.O. Box 17, 3300 AA Dordrecht, The Netherlands

\section{Wolf, Hans-Georg}

\section{A Folk Model of the "Internal Self" in Light of the Contemporary View of Metaphor. The Self as Subject and Object}

Preface and Acknowledgments

1. Introduction

2. Constructionism and a Cluster of Assumptions

3. Metaphor and Construction of Reality

3.1 Lakoff and Johnson Theory of Metaphor

3.1.1 Comments, Reservations, and Criticism

3.1.1.1 The Culture-Body Tension

3.1.1.2 Some Form of Idealism and a Concrete-Abstract Continuum

3.1.1.3 Meaning, Constraints, and Metaphors

3.1.1.4 Lakoff and Johnson's Idea of "Body" and the "Cartesian Anxiety"

4. Metaphoric Models in Folk and Expert Theory

4.1 Models and Metaphors

4.2 Science and Folk and Expert Theory

4.3 Social Science nad the Power of Description

5. 'Self', Language, and Metaphor

5.1 The 'Self' as Nonentity

5.1.1 The "Self' in Language

5.2 The "Self' and Metaphor - A Review

5.3 The "Self' in Cultural and Historical Perspective

6. An Analysis of the "Internal Self'

6.1 Introduction

6.2 Methodological Remarks

6.3 The Internal Self as Universe

6.3.1 The Internal Self as a Closed System

6.3.1.1 The Experiential and Material Self in the Universe of Self

6.3.1.2 The Self as Agent the Universe of Self

6.3.1.3 Entities in the Universe of Self Act upon the Self as Entity and upon Each Other

6.3.2 The Internal Self as a Penetrable System

6.3.2.1 The External World Acts upon the Universe of Self 
6.2.22 Entities of the Universe of Self Cause the Self to Act in the External World

7. Look at Yourself - The Divided Self in the Outside Perspective

8. Conclusion and Perspectives Notes

Bibliography

ISBN 3-631-47840-2

Peter Lang GmbH, Frankfurt am Main 1994

Yu, Ning

The Cantemporary Theory of Metaphor. A perspective from Chinese

Acknowledgments

Chapter 1. Introduction

Chapter 2. The Contemparary Theory: A Review

2.1 Views of metaphor: Claasical vs. contemporary

2.2 Cognitive linguistics and cognitive semantics

2.3 Conceptual and lingnistic metaphors and metaphor system

2.4 Experiential basis of methphor: The notion of embodiment

2.5 Image schemas and the Invariauce Principle

2.6 Conventional and novel metaphors

2.7 Summary of findings of the contemporary theory

2.8 Criticisms of the contemporary theory

2.9 Questions faced by the contemporary theory Chapter 3. Emotion Metaphors

3.1 Language of emotion

3.2 Anger metaphors in English

3.3 Anger metaphors in Chinese

3.4 Happiness metaphors in English

3.5 Happiness metaphors in Chinese

3.6 The underlying model of metaphors

3.7 Summary and discussion Chapter 4. The Time as Space Metaphor

4.1 Conception of space and time

4.2 Alverson's cross-cultural and cruss-linguistic study

4.3 Lakoff's studies in English

4.4 Time as space in Chines

4.4.1 Evidence in the lexicon

4.4.1.1 The past, the present, and the future

4.4.1.2 The verbs in collocation with 'past' and 'future' 
4.4.1.3 Seemingly contradictory cases

4.4.1.4 Spatial terms used in the temporal domain

4.4.2 Evidence in the inference patterns

4.4.2.1 Case One: time as moving object

4.4.2.2 Case Two: time as bounded space

4.4.2.3 The duality: mixture of Case One and Case Two

4.4.2.4 Another case: time and observer moving in the same direction

4.5 Summary and discussion Chapter 5. The

Event Structure of Metaphor

5.1 The conception of events

5.2 The event structure metaphor in English

5.2.1 The location-dual

5.2.2 The object-dual

5.3. The location-version in Chinese

5.3.1 States

5.32 Changes

5.3.3 Causes

5.3.4 Actions

5.3.5 Purposes

5.3.6 Means

5.3.7 Difficulties

5.3.8 Others

5.4 The object-version in Chinese

5.4.1 Attributes

5.4.2 Changes

5.4.3 Causes

5.4.4 Actions

5.4.5 Purposes

5.5 Mixture of location-version and object-version 6 Summary and discussion

Chapter 6. Conclusion

Appendix: The character version of the Chinese examples

References

Name Index

Subject Index

ISBN 90-272-2353-X

John Benjamins B.V., Amsterdam 1998, p. 278

John Benjamins Publishing Co., P.O. Box 75577, 1070 Amsterdam, The

Netherlands 